\title{
The dogs of Roman Vindolanda, Part III: Quantifying juvenilization and pleiotropic effects of miniaturization
}

\author{
DEB BENNETT $^{1 *} \&$ ROBERT M. TIMM ${ }^{2}$ \\ ${ }^{1}$ Deb Bennett, Director, Equine Studies Institute, P.O. Box 411, Livingston, CA, USA \\ ${ }^{2}$ Department of Ecology and Evolutionary Biology \& Natural History Museum, \\ University of Kansas, Lawrence, KS, USA \\ *Corresponding author: office@equinestudies.org \\ Equine Studies Institute, P.O. Box 411, Livingston, CA, 95334, USA
}

(Received 20 May 2017; Revised 18 October 2017; Accepted 20 November 2017)

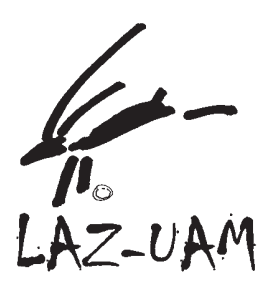

ABSTRACT: In this report we focus on harriers, small dogs of gracile build widely represented in Roman artwork, yet not previously documented from skull or skeletal material. With them we compare remains of other types of small dogs from Vindolanda and other Roman-era sites. Accurate characterization of small dogs requires differentiation between paedomorphy and juvenilization in skull ontogeny. We present a new method for quantifying the degree of juvenilization in dog skulls which is based on understanding the differential development of endochondral and dermal centers of ossification. We enumerate functional and pleiotropic effects of skull and dental morphology and development that are characteristic of miniature dogs but rare in dwarf dogs and in large, normally-proportioned dogs. By comparing a wide array of modern dogs and wolves, we determine the degree to which small gracile dogs of the Roman era differ from primitive, non-juvenilized forms. We employ ratio analysis of dog skull shape utilizing parameters previously indicated by principal component analysis (PCA) as being of high diagnostic value. Although some small and medium-sized domestic dogs have highly juvenilized skulls, equally small skulls from Vindolanda are no more juvenilized than wolves or Dingoes. While small, gracile dogs existed as early as the late Iron Age, we conclude that juvenilization in dogs arose after the Roman era.

KEY WORDS: CANIS FAMILIARIS, DOMESTIC DOG, DWARF DOG, MINIATURE DOG, NEOMORPHY, PAEDOMORPHY, JUVENILIZATION, ROMANO-BRITISH, VINDOLANDA

RESUMEN: Este trabajo se centra en los harriers, perros pequeños de complexión grácil ampliamente representados en el arte romano pero indocumentados hasta la fecha sobre la base de material esquelético. Con ellos comparamos los restos de otros tipos de perros pequeños recuperados en Vindolanda y otros yacimientos de época romana. La caracterización precisa de los perros pequeños requiere diferenciar entre pedomorfía y juvenilización en la ontogenia del cráneo. Presentamos un nuevo método para cuantificar el grado de juvenilización de los cráneos de perro basado en la comprensión del desarrollo diferencial de los centros de osificación dérmicos y endocondrales. Enumeramos efectos funcionales y pleiotrópicos de la morfología craneal y dentaria y del desarrollo que son característicos de perros miniaturas pero infrecuentes en perros enanos y en perros grandes de proporciones normales. Comparando un amplio elenco de perros modernos y lobos determinamos el grado con el cual los pequeños perros gráciles de época romana difieren de las formas primitivas no juvenilizadas. Utilizamos análisis de proporciones de la forma del cráneo canino utilizando parámetros previamente señalados como de alto valor diagnóstico por el análisis de componentes principales (ACP). Aunque algunos perros de tamaño pequeño y medio presentan cráneos extremadamente juvenilizados, cráneos igualmente peque- 
ños de Vindolanda no están más juvenilizados que los de lobos y dingos. Aunque los perros pequeños y gráciles existen ya desde la Edad del Hierro tardía concluímos que el fenómeno de la juvenilización en perros surgió con posterioridad a la época romana.

PALABRAS CLAVE: CANIS FAMILIARIS, PERRO DOMÉSTICO, PERRO ENANO, PERRO MINIATURA, NEOMORFOSIS, PEDOMORFOSIS, JUVENILIZACIÓN, ROMANO-BRITÁNICO, VINDOLANDA

\section{INTRODUCTION}

The terms "small," "miniature," "dwarf," and "paedomorphic" are often used interchangeably in describing the remains of small dogs recovered from archaeological sites. The proper use of this terminology becomes important as researchers seek to differentiate between different types of "small" dog. We follow Baxter (2002, 2010 a, b) in considering a "dwarf" dog to be one that is short in stature as the result of a syndrome of abnormally-timed developmental events called achondroplasty or chondrodysplasia. In dogs, the syndrome results from a mutation affecting a single protein (Parker et al., 2009). Miniaturization by contrast appears to derive from disturbances in endocrine function that affect the timing and quantity of hormone output from the thyroid gland (see review in Crockford, 2000).

Small dogs with gracile build can be divided into two types - miniatures and harriers. Baxter
(2010 a) recognizes minatures such as those from the Roman-era sites of Thistleton, Silchester, and Yasmina, which have tiny, bulbous skulls less than about $120 \mathrm{~mm}$ in basal length and calculated shoulder height of no more than $30 \mathrm{~cm}$. They were valued as pets but also likely functioned to catch rats and mice. Miniature dogs were present at Vindolanda but were uncommon and to date are represented only by jaws and postcranial material.

Harriers are small sight hounds (Figures 1,21A, Plates I-V) distinguished not only by gracility but backsloping occiputs which assist in fast locomotion. Their skulls are a little larger than those of miniatures, up to about $150 \mathrm{~mm}$ in basal length, and they may stand up to $46 \mathrm{~cm}$ at the shoulder. This type has not previously been recognized from bony remains, although images of them are frequent in Roman artwork (see Bennett \& Timm, 2016, figures 12, 14G; Figure 21A this paper). Harriers are bred for coursing small game including hares, foxes, and birds.

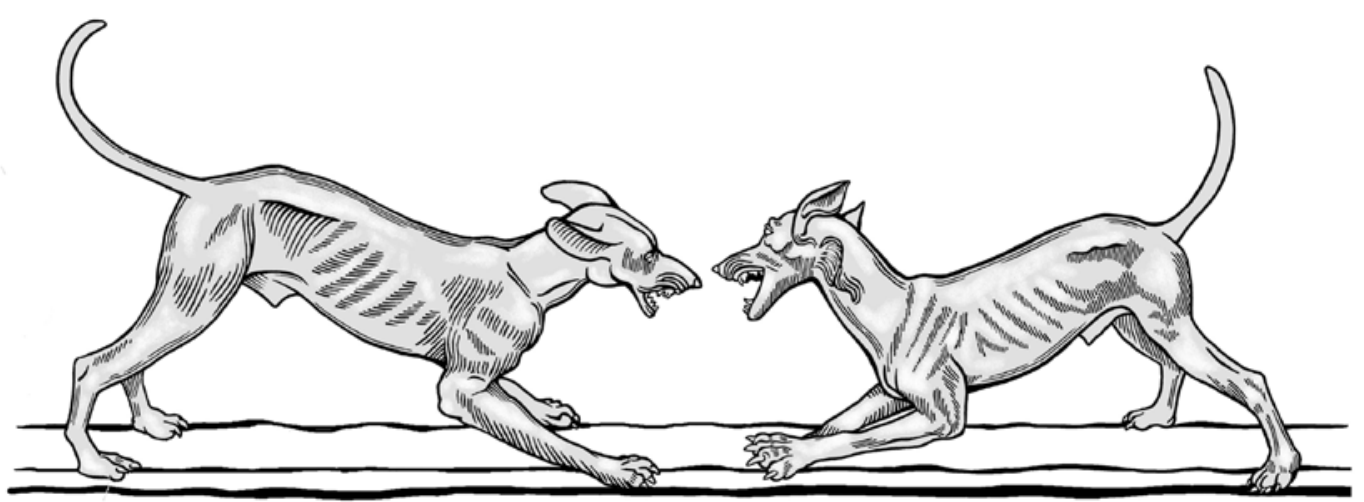

FIGURE 1

A brace of dogs exemplifying harrier type as represented in a life-sized bronze sculpture group recovered from first-century Pompeii. The dogs stand about $45 \mathrm{~cm}$ at the withers; note the lithe build, long whiplike tail, small head with rather pointed muzzle, and long "bat" ears. Representations of miniatures in Roman artwork are much more rare. Facsimile drawing by author Bennett; courtesy, National Archaeological Museum of Naples. 

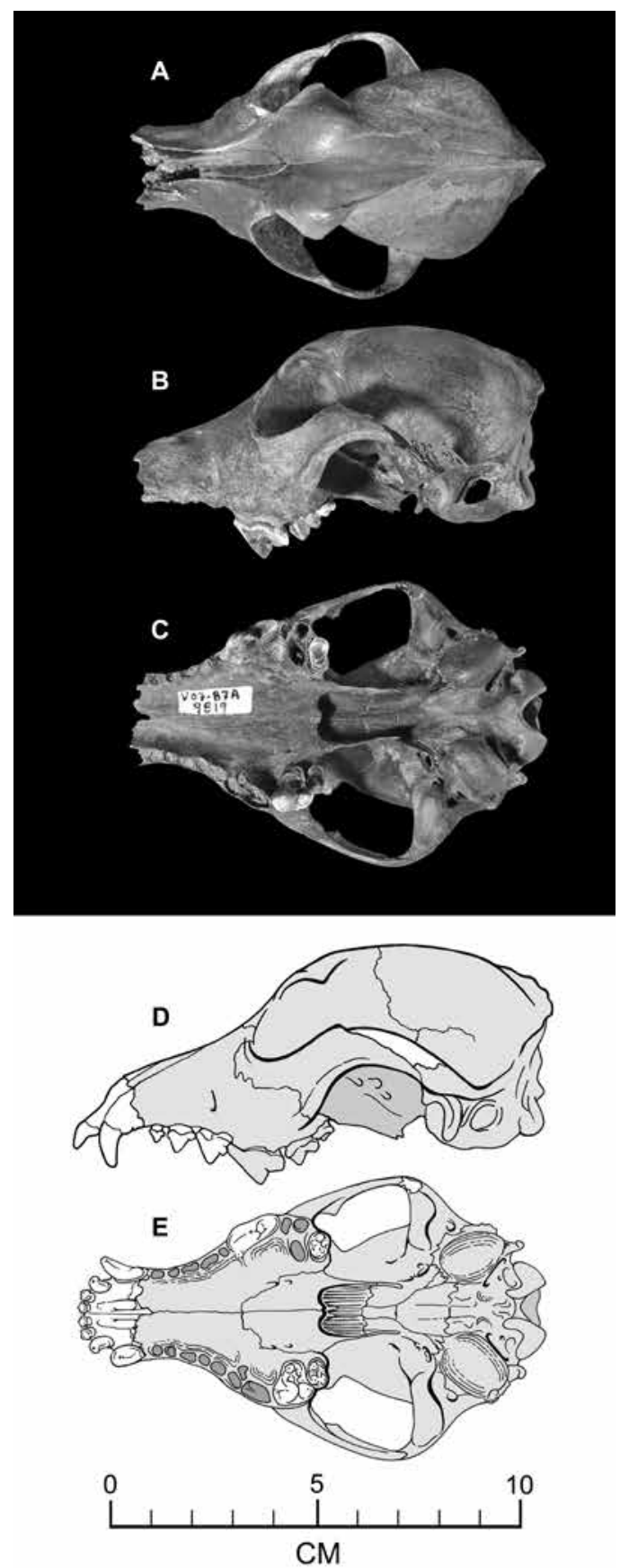

PLATE I

Vindolanda skull V07-87A 9819. A, dorsal; B, lateral; C, ventral views with restorations in $\mathrm{D}$, lateral and $\mathrm{E}$, ventral view.

Paedomorphy and neoteny are essentially synonymous terms from developmental anatomy denoting the retention of juvenile characteristics past
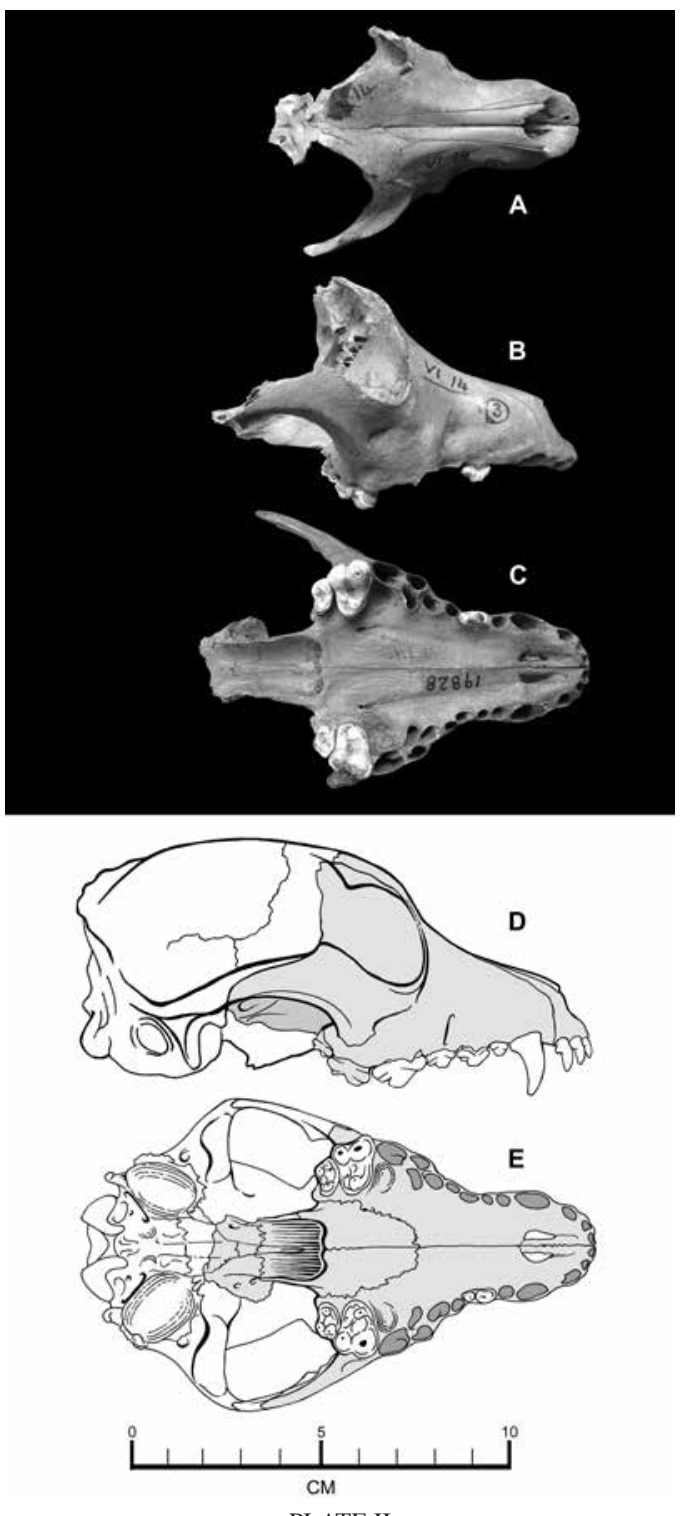

PLATE II

Vindolanda skull VI-14 19828. A, dorsal; B, lateral; C, ventral views with restorations in $\mathrm{D}$, lateral and $\mathrm{E}$, ventral view.

sexual maturity. Paedomorphy is an example of heterochronic development, i.e., it arises as a result of a change in the normal timing of developmental events. Zoologists have often regarded domestic dogs as paedomorphic wolves, but Drake's thorough $(2004,2011)$ studies show that few breeds of domestic dog follow the same developmental pathway as wolves and thus most cannot correctly be termed "paedomorphic". Her most important finding is that puppy skulls of most modern breeds 

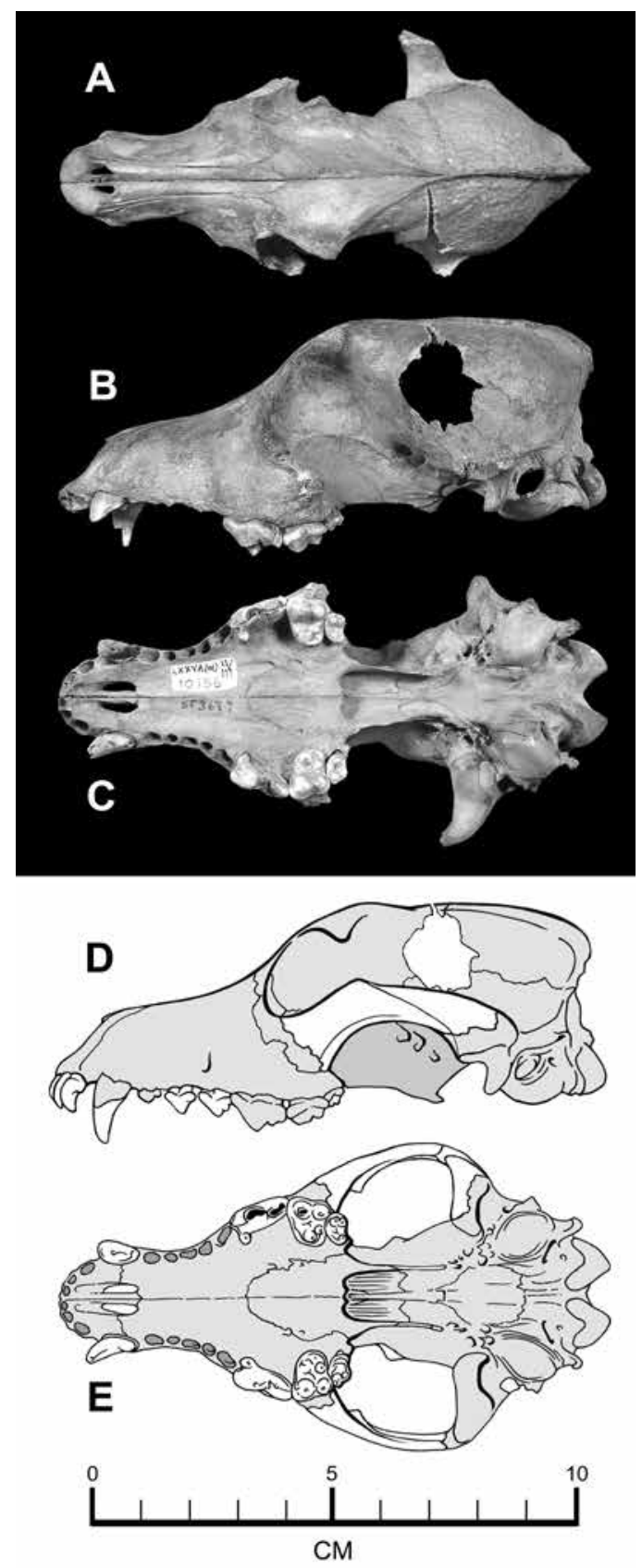

PLATE III

Vindolanda skull LXX-VI (W) 11/111 10156. A, dorsal; B, lateral; $\mathrm{C}$, ventral views with restorations in $\mathrm{D}$, lateral and $\mathrm{E}$, ventral view.

are, at any given stage of development, unique in shape, as are the final adult shapes. They are thus examples not of paedomorphy but of neomorphy - a mutation causing novel gene function.

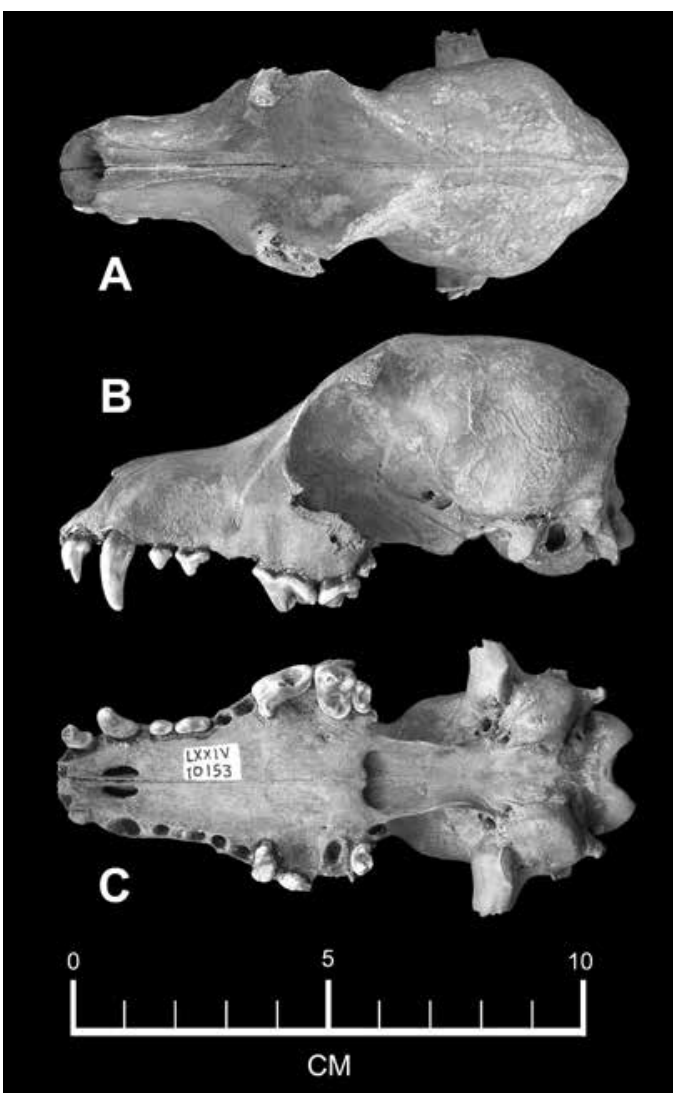

PLATE IV

Vindolanda skull LXXIV 10153. A, dorsal; B, lateral; C, ventral view (for restorations see Figure 19).

The intense selective breeding that produces neomorphy can result in novel adult skull morphology (Drake \& Klingenberg, 2008), and can also result in morphological convergence. Huber (1974) suspected that there must be several modes by which reduction in basal length (BL) might be achieved to produce "puppy-like" adult skull shape. In consideration of Drake's $(2004,2011)$ definitive results, we avoid the terms "paedomorphic" and "neotenic" because we cannot be certain which developmental pathway any given modern or ancient dog may have followed. We can, however, demonstrate that particular skull elements failed to grow (i.e., by measuring the dimension Px, see Figures 2,3). Skulls with short Px are "juvenilized," a term that implies no particular ontogenetic regimen. In this report, we show that in all juvenilized dogs, the palatine fails to lengthen after puppyhood, and this is what our index $(\mathrm{Px} \times 100) / \mathrm{CP}($ Figure 3$)$ is designed to quantify. 


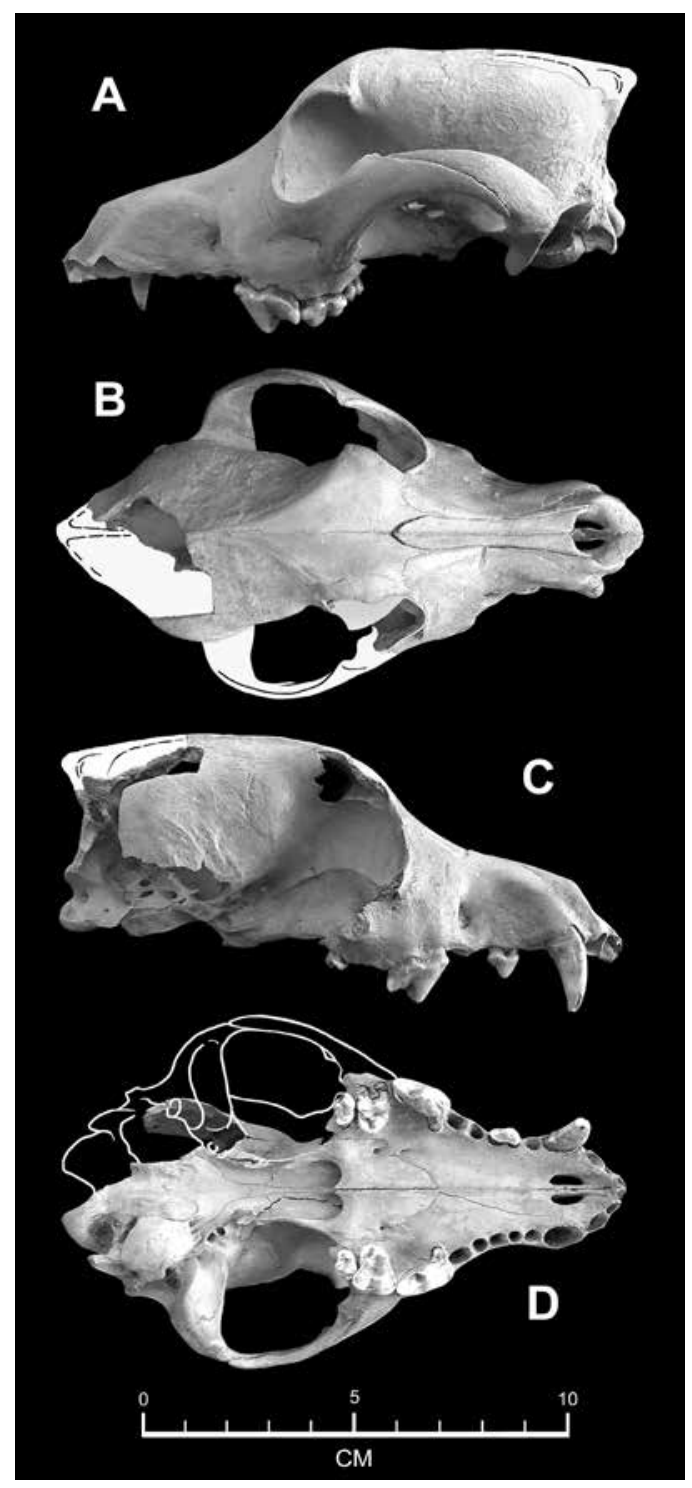

PLATE V

Vindolanda skull VI-14 50B 29560. A, left lateral; B, dorsal; C, right lateral; D, ventral views.

The deliberate production of small, gracile dogs begins in the late Iron Age about 2100 years ago and marks a highly significant development in the history of animal husbandry because such bloodlines cannot be maintained without conscious selection and the sequestration of breeding-ready females. This is in contrast to dwarf dogs, which may spontaneously appear in a litter because the gene complex which produces dwarfing is inherited as an autosomal dominant (Parker et al., 2009).

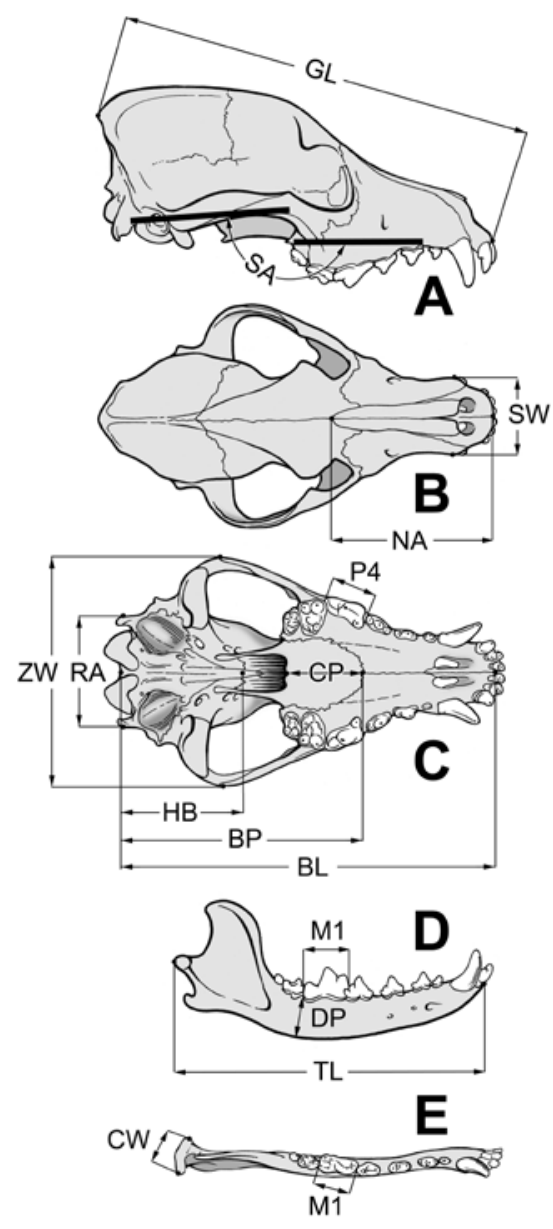

FIGURE 2

Skull measurements utilized in this report.

Dwarf dogs are common in Roman-era sites in Europe, but are also known from sites up to several thousand years old in both hemispheres, for example Old Kingdom Egypt (Churcher, 1993) and pre-Hispanic Mexico (Azúa, 2000).

The well-preserved sample of dogs from Vindolanda dates from the crucial period during which small, gracile dogs were first deliberately bred. The Vindolanda collection is important because it antedates widespread intercrossing of European lineages that began in the $18^{\text {th }}$ century, and which has made elucidation by DNA analysis of the relationships of modern dog breeds confusing and difficult (Larson et al., 2012; Thalmann et al., 2013). In previous papers, we document an array of dogs from Vindolanda and contemporary sites 


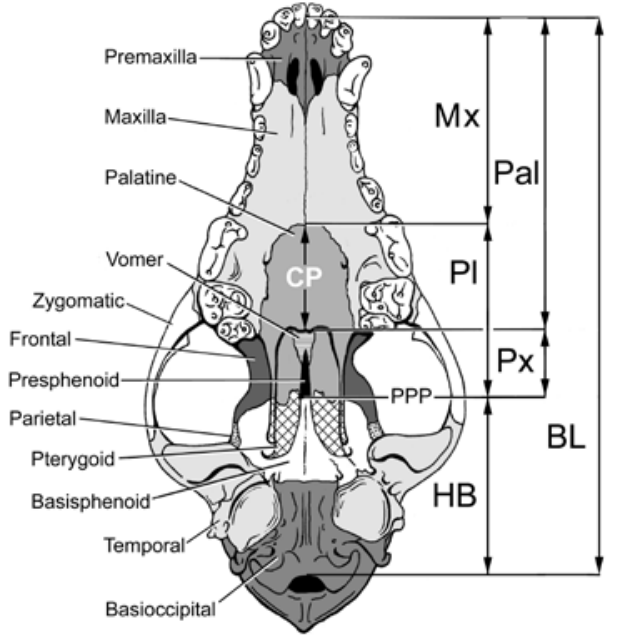

FIGURE 3

Bones of ventral dog skull. Distances delineated by arrows are the Lüps-Huber method of measuring the chain of bones that compose the basicranium. The location of junction PPP and the dimension Px also shown (see text for explanation).

(Bennett et al., 2016; Bennett \& Timm, 2016). Such diversity represents an early differentiation from primitive, generalized wolf-like or Dingo-like morphology which has culminated in the highly distinctive appearance, behavior, and functioning of at least some modern dog breeds. In order to determine the degree to which the small, gracile dogs of Vindolanda diverge from wild and feral (primitive, non-juvenilized) morphology, we compare them with a wide array of small modern domestic dogs and small dogs reported from other Romano-British and Roman-era sites, and with North American and Indian wolves, Australian Dingoes, and New Guinea Singing Dogs.

Herein, we present a new method for quantifying the degree of juvenilization in dog skulls which is based on understanding the differential development of endochondral and dermal centers of ossification in the skull (Figures 4-8). We employ ratio analysis of skull shape utilizing parameters previously indicated by principal component analysis (PCA) as being of high diagnostic value (Bennett et al., 2016) (Figures 9-17).

\section{STUDY SITE}

Vindolanda is a Roman-era fort and village site located $3 \mathrm{~km}(2 \mathrm{mi})$ south of Hadrian's Wall in
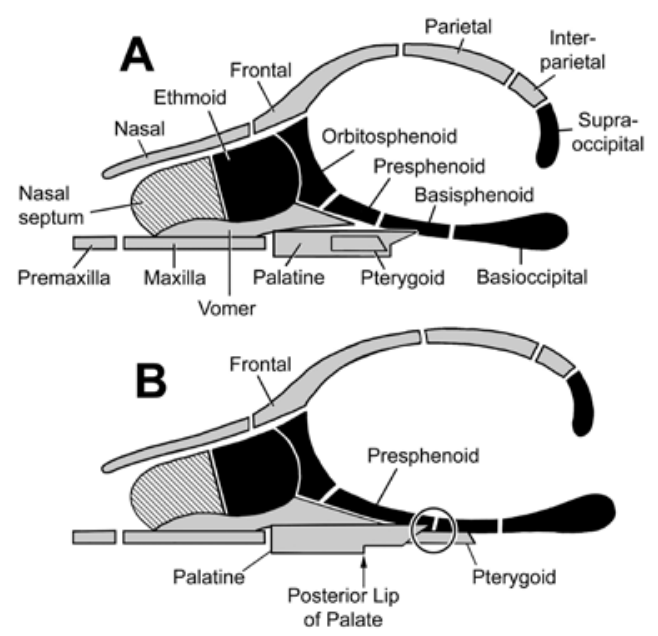

FIGURE 4

Skull growth diagram modified after Huber (1974). Black = bones of endochondral origin, gray = bones of dermal origin, hatching $=$ midline cartilagenous element. $\mathrm{A}$, configuration in puppy; B, configuration in adult dog. Circle in view B marks the pterygoid-palatine suture, where the palatine meets the presphenoid. From puppyhood onward, all three bones lengthen, but the presphenoid and pterygoid lengthen the most, so that the point where the pterygoid meets the presphenoid comes to lie behind the rear lip of the palate. In the skulls of puppies and juvenilized adult dogs, the suture lies far forward (see Figures 6-7).

northern England, from which have come abundant well-preserved remains of domestic dogs (Canis familiaris). The earliest Roman habitation of the site dates to about 85 A.D., and habitation persisted thereafter nearly continuously for over three centuries under Roman aegis. Details of site location, stratigraphy, architectural context, and ethnography are previously reported, as are the abundance and morphological range of the dog remains (Bennett et al., 2016; Bennett \& Timm, 2016). Methods of excavation and the history of excavation at this site are outlined in Birley (2003), Blake (2014), and Bennett et al. (2016).

\section{MATERIALS AND METHODS}

\section{Specimens Examined}

The complete collection of dog skulls from Vindolanda comprises 29 individuals; we focus on 7 of these for this report. Included skulls were selected on the basis of small size (BL $=107$ to $144 \mathrm{~mm}$, Figure 2) and gracile build. Five specimens exhibit 

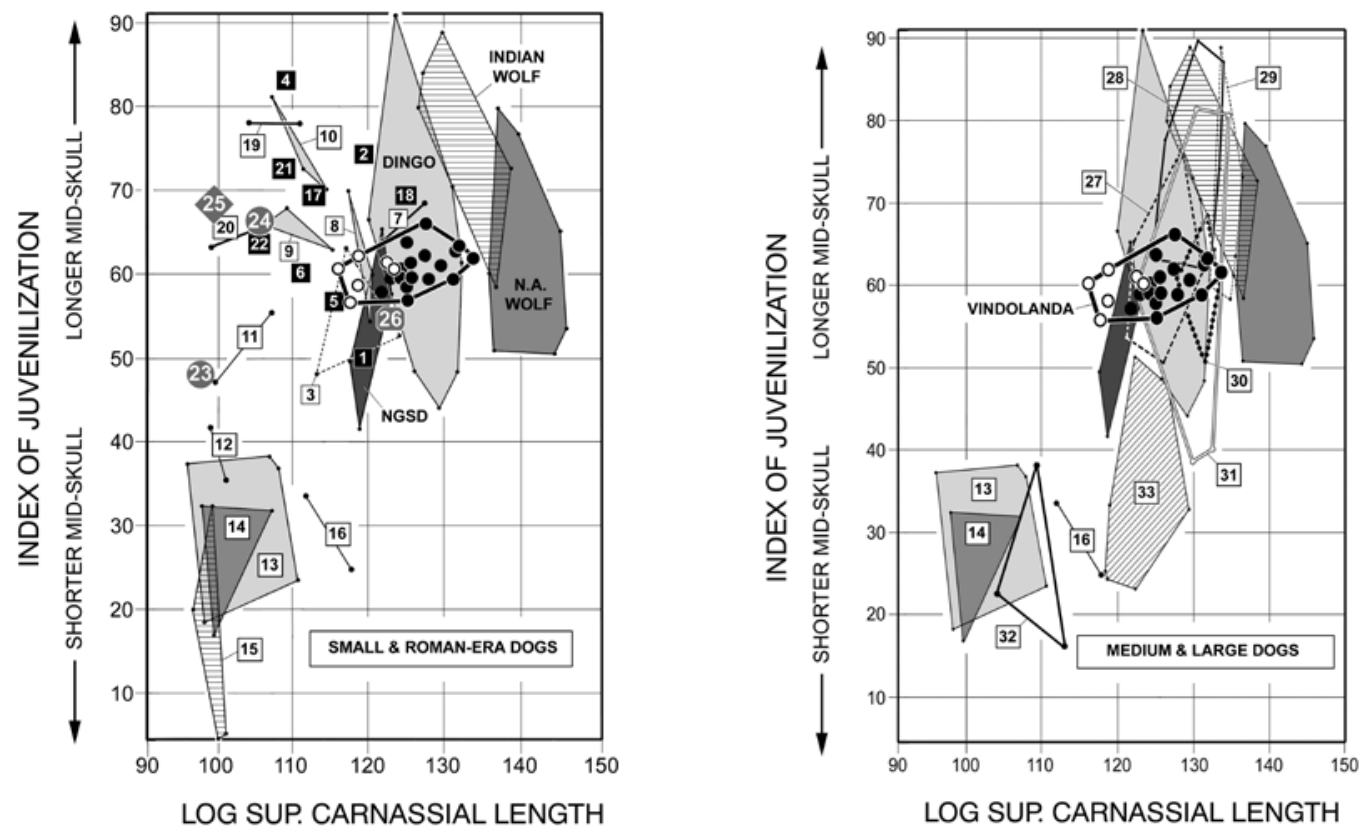

FIGURE 5

MTA diagrams charting the degree of juvenilization in the basicranium. For ease of viewing, the chart has been divided into two parts which highlight smaller (A) and larger (B) breeds. All Vindolanda dog skulls, whether small or large, are plotted (heavy boundary, large dots). White dots = Vindolanda dogs analyzed in this report; black dots = Vindolanda dogs not analyzed in this report.

Included in both halves of this MTA are the "outgroups" - wild and feral types which give the scale for all comparisons: medium gray = North American wolf; horizontal hatching = Indian wolf; light gray = Australian Dingo; dark gray = New Guinea Singing Dog (NGSD). Four Roman-era dogs not from Vindolanda are also included (gray symbols); for restorations of these dogs see Figure 8. The position of the Yasmina, Thistleton, and Linton skulls are estimates because of breakage and tooth loss.

Key to numbered specimens: 1 = Small dog from near Baghdad, Iraq; 2 = Patterdale (English) Terrier; 3 = English Water Spaniel; 4 = Skye Terrier; $5=$ Spitz; 6 = small spaniel of unknown breed; $7=$ Scottish Terrier; $8=$ Dachshund; $9=$ Lhasa Apso; $10=$ Mexican Hairless; 11 = Pomeranian; 12 = Maltese; 13 = Pekingese; 14 = Chihuahua; 15 = Cavalier King Charles, Japanese Chin, and Griffon Brusselois; $16=$ Boston Terrier; $17=$ Silky Terrier; $18=$ West Highland Terrier; $19=$ Yorkshire Terrier; $20=$ Toy Poodle; $21=$ Miniature Doberman Pinscher; 22 = Affenpinscher; 23 = Dog from Yasmina (MacKinnon and Belanger, 2002); 24 = Dog from Linton, U.K. (Baxter, 2010a, b); 25 = Dog 1441 from Thistleton, U.K. (Baxter, $2010 \mathrm{a}, \mathrm{b}) ; 26=$ Dog 1228 from Thistleton (Baxter, $2010 \mathrm{a}, \mathrm{b}$ ); 27 = Chow-chow, SharPei, and selected Iraqi bulldogs; $28=$ German Shepherd and Alsatian; $29=$ St. Bernard; $30=$ Newfoundland; $31=$ Mastiff; $32=$ Pug; 33 = English Bulldog.

a backsloping occiput (Plates III-VII) while in V07-87A 9819 -the smallest in the sample- the occiput is strongly forward-sloping or "tucked under" (Plate I; occiput is missing in VI-14 19828, Plate II). Features commonly associated with miniaturization such as bulbous cranium, "keyholing" of the foramen magnum, sagittal crests small or lacking, relatively small muzzle, and relatively large orbits are present, at least to some degree, in all (Figure 18). Although their skulls may be equally small, dwarf dogs display rugged build (heavy cresting, thicker bone) and have forward-sloping occiputs; we analyze dogs with this morphology in an upcoming report (Bennett \& Timm, in prep.).

The Vindolanda collection also contains 37 unassociated dog rami, of which 13 are of a size to match skulls with basal length of between about $116-155 \mathrm{~mm}$. The smallest recovered postcranial elements suggest the presence of even smaller dogs at Vindolanda, true miniatures that stood no more than $28 \mathrm{~cm}$ at the shoulder. None of the Vindolanda skulls or rami herein reported are associated, and none have associated postcrania.

For purposes of comparison, we examined and measured 504 recent dog skulls. Our database for the Australian Dingo (Canis familiaris dingo) comprises 150 skulls, but because intermixture with domestic dogs has tended to increase with time since Australia was colonized by Europeans at the end of the 18th century (Corbett, 1995), we limit comparison to a subset of 45 Dingo skulls collected prior to 1940 . We also examined skulls of puppies of do- 


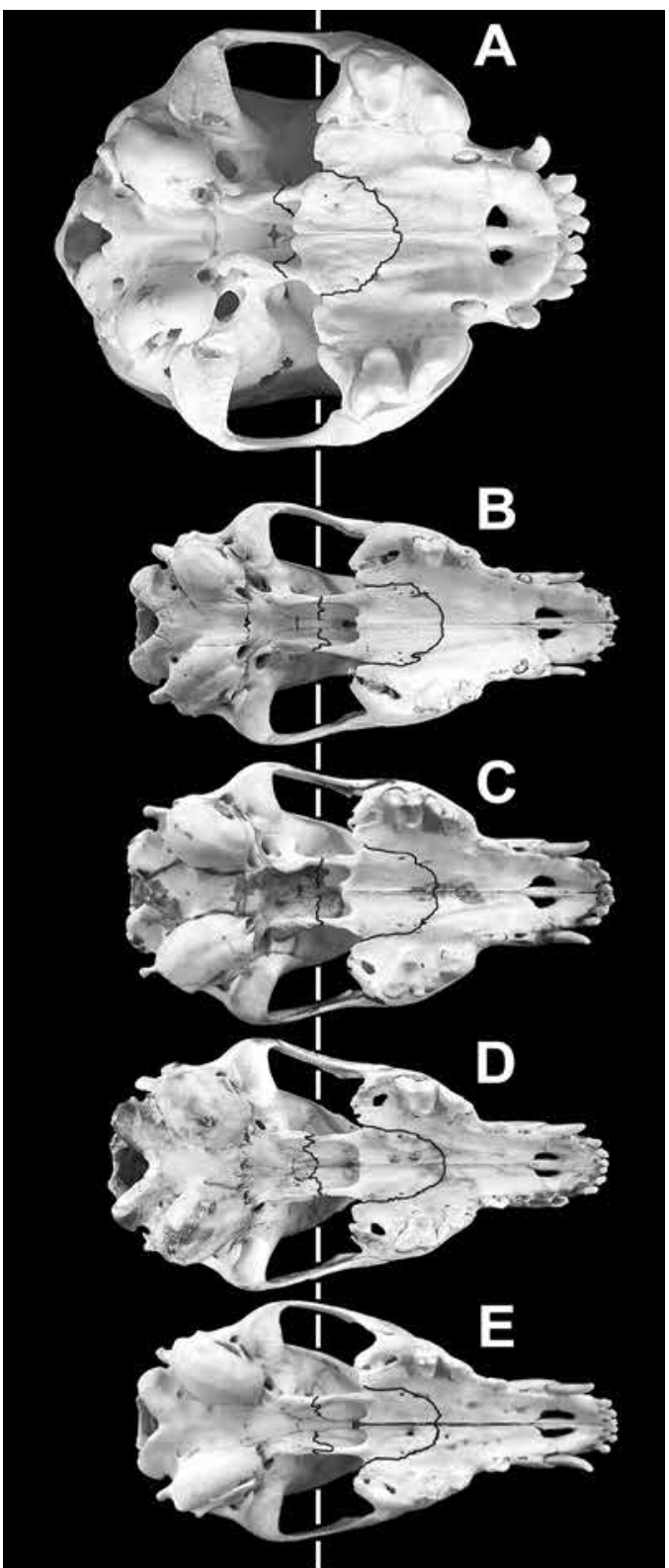

FIGURE 6

Skulls of juvenile canids, rendered to the same length to make proportional differences stand out. The skulls are aligned on the white line, which marks the position of the PPP junction in each. For ease of viewing, the pterygoid-palatine suture has been enhanced by a black line. A, skull of a juvenilized breed, Chihuahua (SKU 1505 with BL $=47.83 \mathrm{~mm}$ ). B, skull of a non-juvenilized breed, Labrador Retriever (KU 169644 with $\mathrm{BL}=126.54)$. C, Wolf (KU 3384 with BL =90.50). D, Coyote (KU 35540 with $\mathrm{BL}=99.59)$. E, Red fox (KU 47964 with $\mathrm{BL}=91.51)$. Note that (B) is somewhat younger than the others; its permanent carnassial has not yet erupted, yet its PPP junction already lies far posterior to the palatal lip and Px is actually longer in it than in C. PPP lies ahead of the palatal lip in view A.

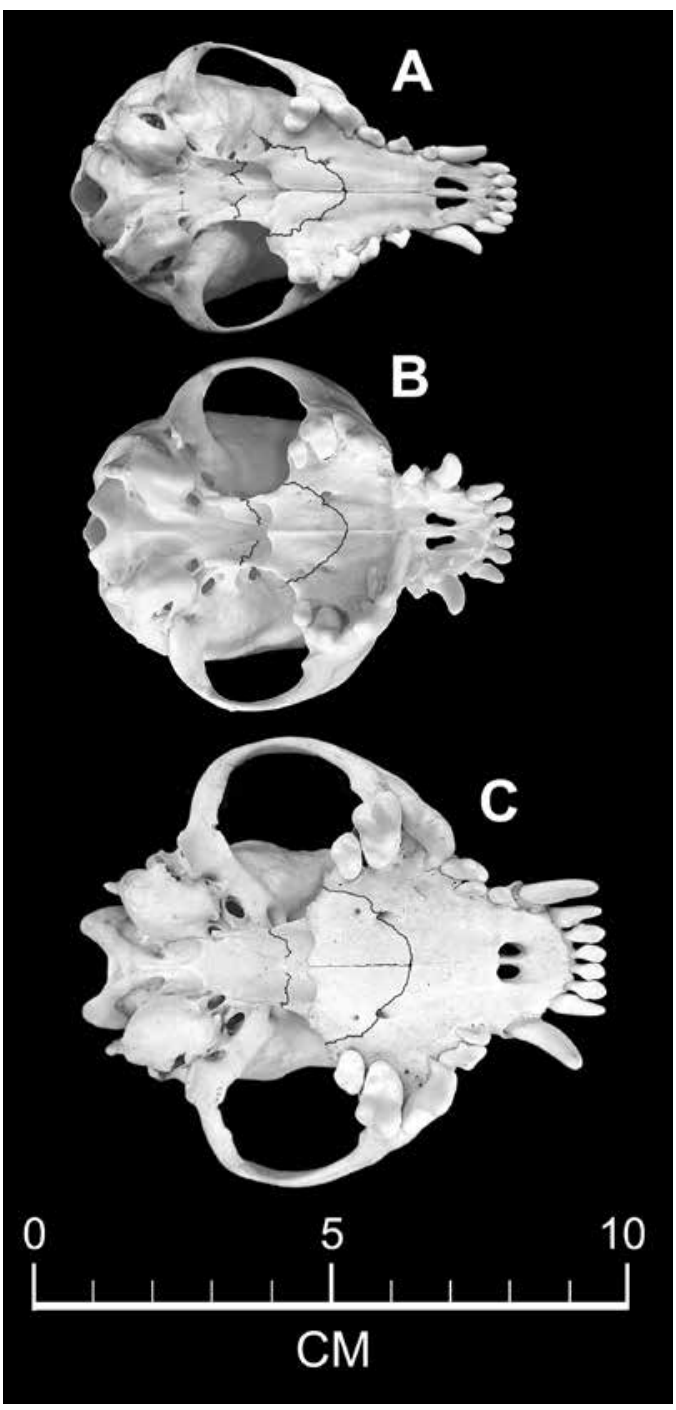

FIGURE 7

Skulls of juvenilized adult dogs belonging to small breeds. After the middle of the 19th century, and particularly after 1950, breeder selection has acted to increase the degree of juvenilization of many breeds; Chihuahuas shown here are but one example. A, Chihuahua AMNH 90210, collected 1931 with $\mathrm{BL}=66.16 \mathrm{~mm}$. B, Chihuahua SKU 1505, collected 2005 with $\mathrm{BL}=63.98$. C, Pekingese LACM 30535 collected in the mid-1930's with BL= 78.15. For ease of viewing, the pterygoid-palatine suture and the palatal suture have been enhanced with black lines.

mestic dogs, North American wolves, Coyotes, and North American Red Foxes (Figure 6). Datasets utilized number as follows: North American Wolf ( $\mathrm{Ca}$ nis lupus) $\mathrm{n}=85$; Indian Wolf (Canis lupus pallipes) $\mathrm{n}=8$; New Guinea Singing Dog (Canis familiaris hallstromi) $\mathrm{n}=6$. In some analyses, one or two fewer specimens may be included because of breakage. 


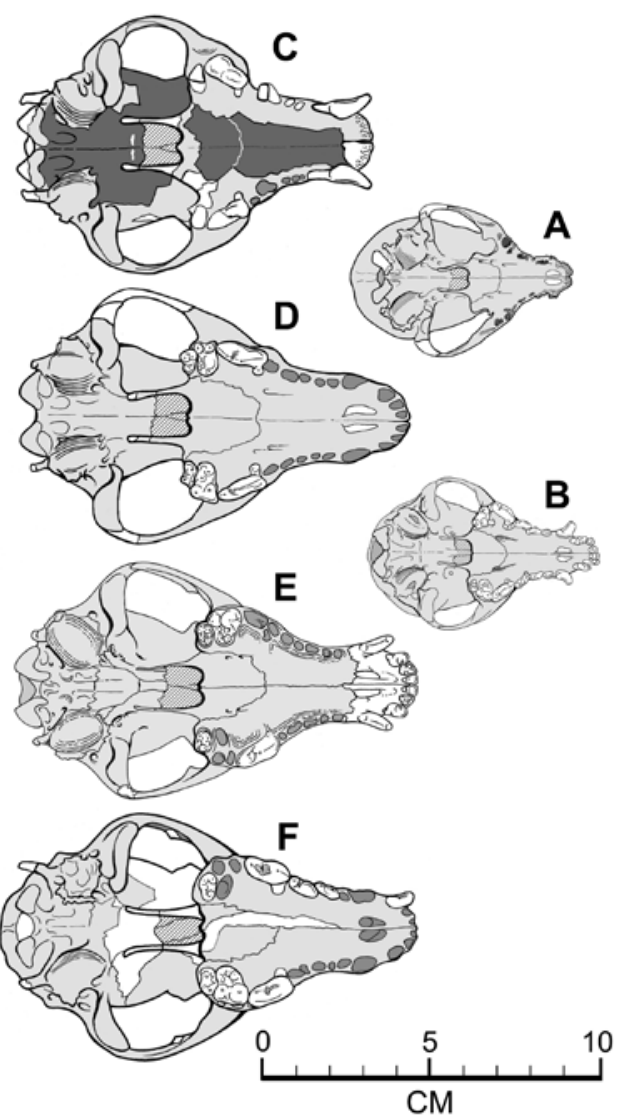

FIGURE 8

Restored ventral views of small Roman-era dogs and a recent dog for comparison, to scale. A, Yasmina (GL about $80 \mathrm{~mm}$; Baxter, pers. comm.). B, Maltese collected in 1918 (AMNH 61587, GL = 88.77). C, Thistleton 1441 (GL about 116 mm; Baxter, 2010a, b). D, Thistleton 1228 (GL about $129 \mathrm{~mm}$; Baxter, $2010 \mathrm{a}, \mathrm{b})$. E, the smallest nearly complete skull from Vindolanda (V07-87A 9819 with GL about $128 \mathrm{~mm}$ ). F, Linton (GL about $131 \mathrm{~mm}$ (Baxter, $2010 \mathrm{a}, \mathrm{b}$ ). Although the position of PPP in C and $\mathrm{F}$ is estimated due to breakage, we believe that no dog of the Roman period reached adulthood with PPP close to or covered by the palate. Note that the position of PPP in view B also lies well behind the posterior palatal lip.

Because good comparative views of archaeological dogs have only rarely been published, we present standard diagnostic views of the Vindolanda skulls along with three recent dogs with strikingly similar morphology (Plates VIII-X) which plot close to the Vindolanda dogs in all graphic analyses (Figures 9-17). We compare four nearly complete Roman-era dog skulls reported by Baxter (2010 a, b) and MacKinnon \& Belanger (2002) (Figure 8). Reconstructions based on photographs are provided for incomplete material. We also pres-

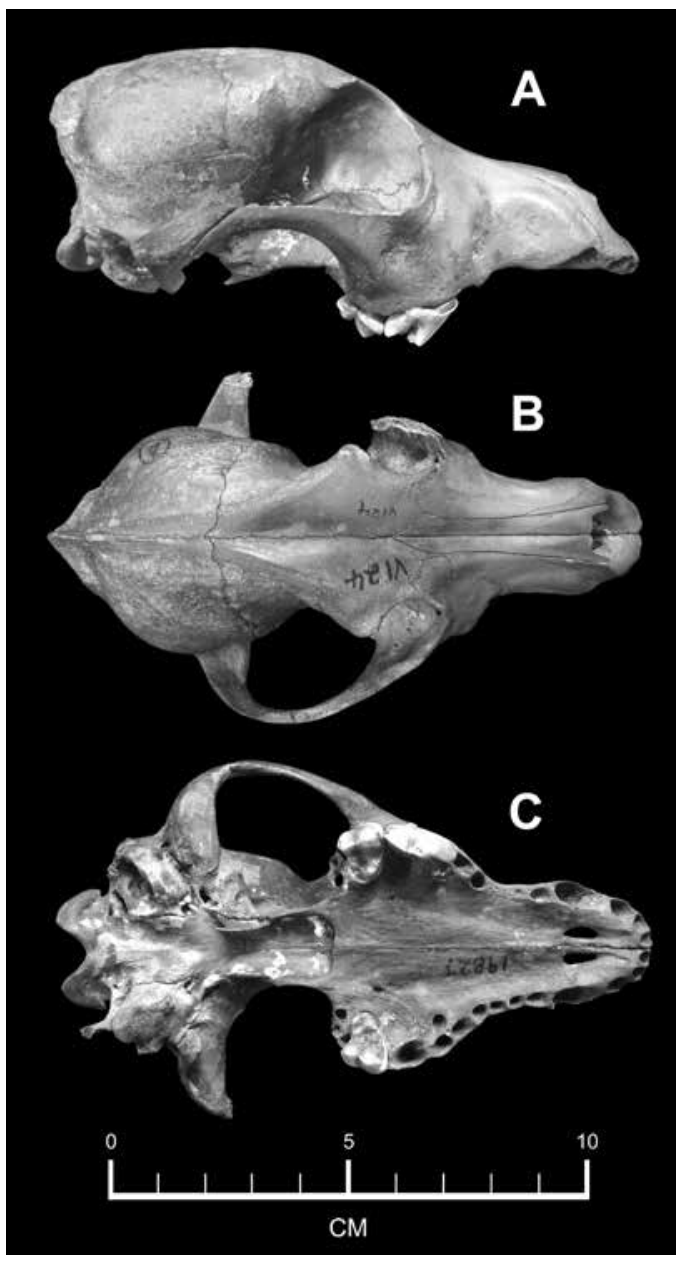

PLATE VI

Vindolanda skull VI-24 19827. A, lateral; B, dorsal; C, ventral views.

ent X-ray studies of one adult and one juvenile Vindolanda dog ramus (Figure 20).

\section{The Juvenilization Algorithm}

Because the growth of endochondral vs. dermal bones is controlled by several different gene-mediated factors (Drake, 2004), it may proceed at different rates. Nussbaumer's useful (1978) method of measuring the basicranium is based on foregoing work by Lüps (1974) and Huber (1974). Huber (1974) compared 15 medium to small-sized dog breeds utilizing the formula $(\mathrm{Mx}+\mathrm{Pl}) \times 100 / \mathrm{B}$ 

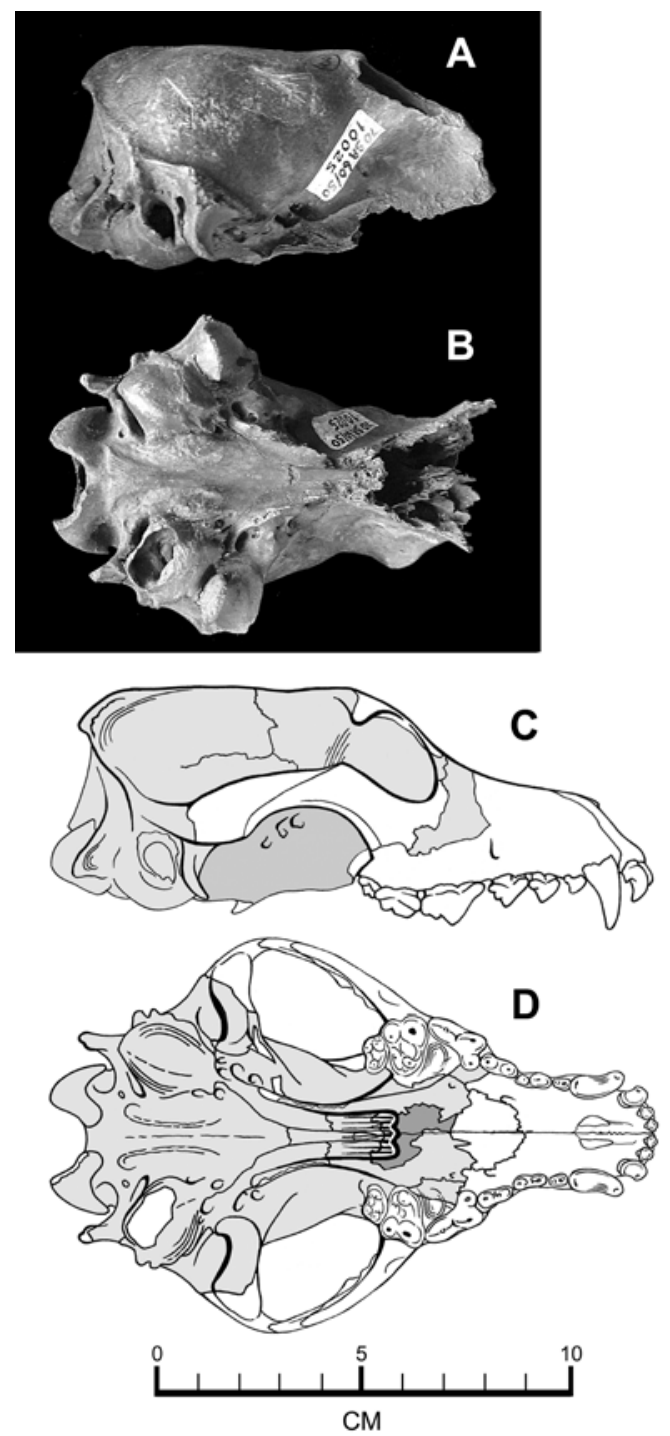

PLATE VII

Vindolanda skull 70-SA 60/50 10025. A, lateral; B, ventral views with restorations in $\mathrm{C}$, lateral and $\mathrm{D}$, ventral view.

(Figure 3). Following this suggestion, we examined skulls of puppies and domestic dogs, Wolves, Coyotes, and Red Foxes (Figure 6).

Our algorithm $(\mathrm{Px} \times 100) / \mathrm{CP}$ is a powerful tool for quantifying juvenilization which compares the position of the pterygoid-palatine-presphenoid junction (PPP) to the posterior lip of the hard palate (Figures 3,4). These measurements are not made directly because the palate does not lie on the same plane as the basicranium. Instead, we utilize Photoshop measurements of standardized digital images

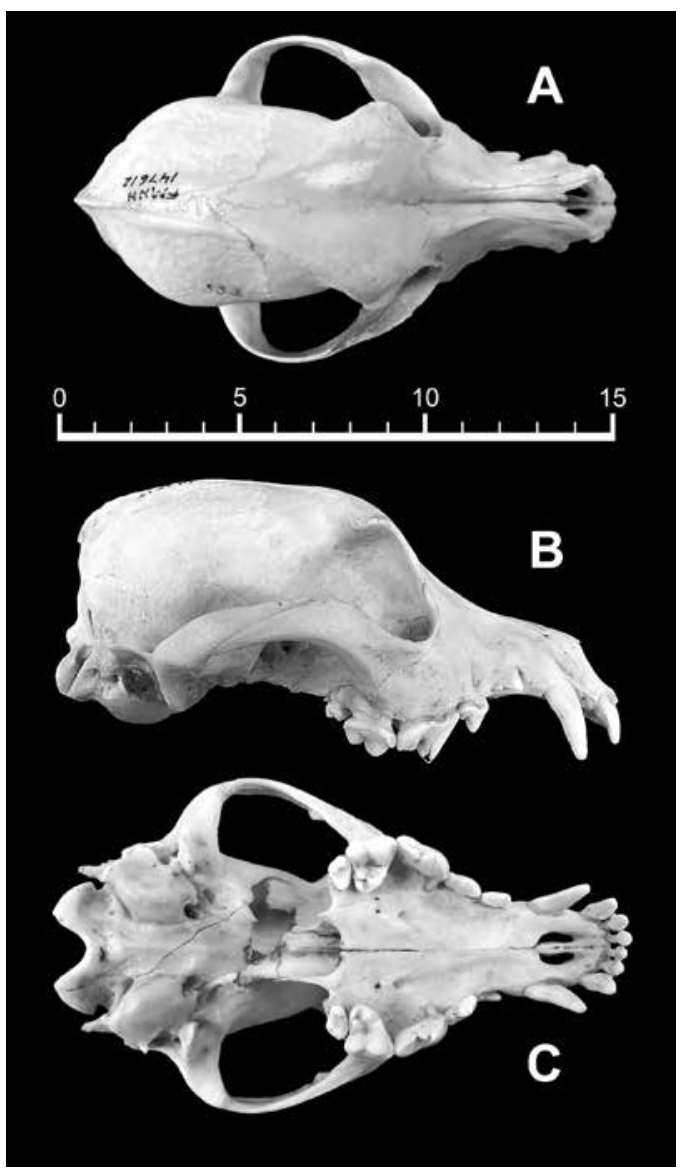

PLATE VIII

Recent domestic dog skull, a Patterdale (English or Lakeland) Terrier, FMNH 147612. A, dorsal; B, lateral; C, ventral views.

of the ventral skull. This method has the advantage of allowing direct comparison - within reasonable range of error-to published images of dog skulls. It requires only the center section of the skull, and thus can be performed on archaeological skulls that are missing the face or braincase.

Both our method and Huber's (1974) can be used to reveal differential growth in the ventral cranium because both probe the same thing - the amount of elongation that the presphenoid bone (Figure 4) undergoes during development, reflected by how far the junction PPP lies behind the posterior lip of the palate at any given stage of development. In our MTA analyses, however, we prefer $\mathrm{CP}$ as the ratio denominator because it consistently represents about $34 \%$ of the total length of the palate in all dog breeds, whereas both B and $\mathrm{BP}$ vary considerably (see figure 11 in Bennett et 


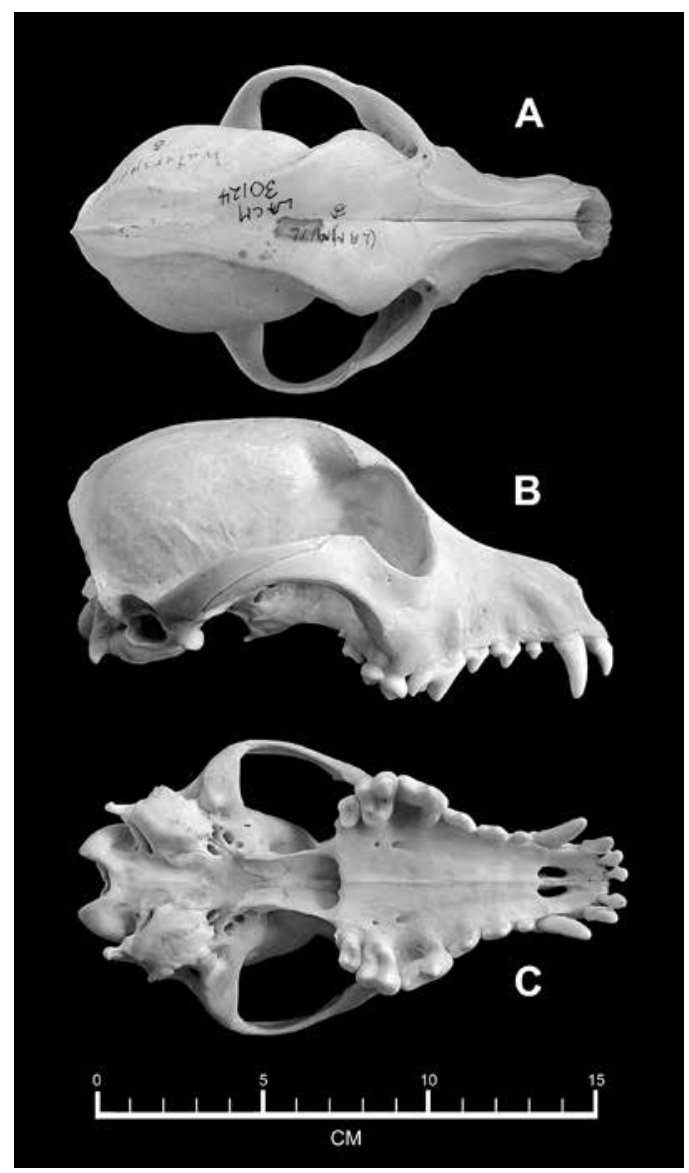

PLATE IX

Recent domestic dog skull, an English Water Spaniel, LACM 30124. This breed became extinct in the 1930's. A, dorsal; B, lateral; $\mathrm{C}$, ventral views.

al., 2016). Likewise, we prefer Px to Mx because $\mathrm{Px}$ is independent of shortening or lengthening of the snout relative to the putative primitive morphology represented by the wolf or Dingo.

\section{Multivariate Analyses}

A clear description of principal component analysis (PCA) used in this series of papers, and our rationale for preferring PCA to discriminant function analysis (DFA) and to canonical variate analysis (CVA) are given in Bennett et al. (2016). Analyses were preformed using the PAST software package (Hammer et al., 2001).
Mazzorin-Tagliacozzo analyses (MTAs, Figures 9-17) represent a graphic-analytical method in which a ratio, index, or proportional relationship is set against a measurement reflective of overall size to form a bivariate plot. Ideally, the two parameters which make up the ratio axis are selected on the basis of high discriminatory power as indicated by the results of principal component analysis; we previously performed and reported PCAs from which we derive many of the MTAs in this report (Bennett et al., 2016). Other MTAs herein presented are not based on PCAs but rather upon indexes considered by Harcourt (1974), Huber (1974), Lüps (1974), or Nussbaumer (1978) to have high discriminatory power (Figures 9-11). Successful MTA analysis shows a diagonal "spread" of hulls pertaining to different groups, in other words the groups separate along both the size axis and along the ratio axis. We prefer MTA analyses because

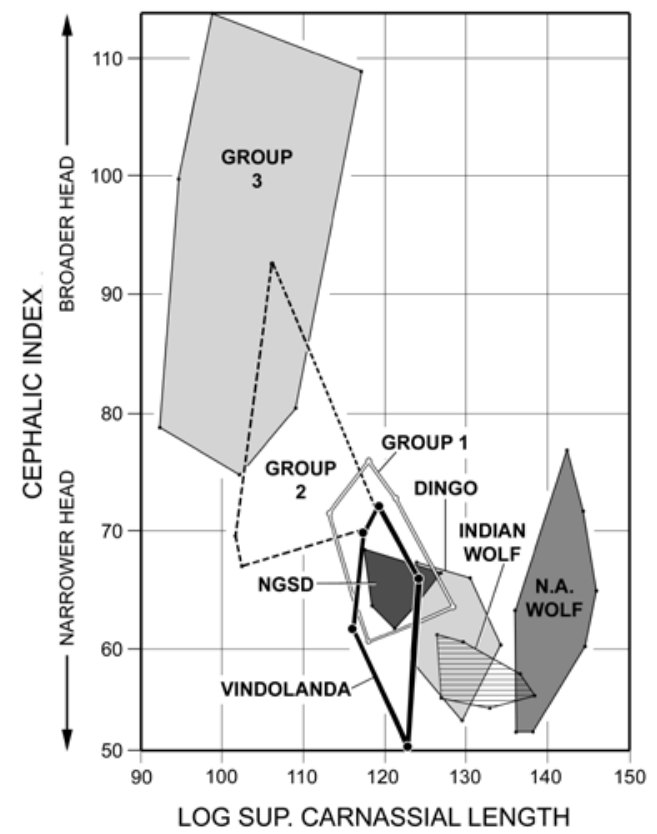

FIGURE 9

Harcourt's (1974) Cephalic index $(\mathrm{ZW} \times 100) / \mathrm{BL}$ rendered as an MTA by plotting it against log superior carnassial length, a good proxy for overall body size. Key to dog skulls included in Group 1, Group 2, and Group 3 (applies also to Figures 9 through 16): Group 1 = Patterdale (English) Terrier, Spitz, Dachshund, Water Spaniel, Scottish Terrier, small dog from Baghdad; Group 2 = Miniature Doberman Pinscher, Yorkshire Terrier, Skye Terrier, West Highland Terrier, Mexican Hairless, Lhasa Apso; Group 3 = Griffon Brusselois, Japanese Chin, Cavalier King Charles Spaniel, Maltese, Toy Poodle, Pomeranian, Chihuahua, Pekingese, Affenpinscher, Jack Russel Terrier, Boston Terrier. 
they are relatively simple to produce and because their interpretation is straightforward (Bennett et al., 2016).

\section{RESULTS AND DISCUSSION}

\section{Morphological Range}

Harcourt's (1974) groundbreaking morphological studies of British dog remains set a high standard for archaeological dog studies. Given his wide-ranging investigations, however, it is somewhat surprising that Harcourt concludes that dogs of the British Iron Age "were in terms of head shape, what can best be described as plain 'dog', that is, entirely unmodified" (1974: 60). Harcourt does not specify what he means by "plain dog", but presumably he had the Dingo in mind as it has generally been considered to represent primitive morphology in domestic dogs (Corbett, 1995; Smith \& Litchfield, 2009; Fillios \& Taçon, 2016). The morphological range of known European and North African Iron Age and Roman-era dogs is in fact large (Bennett et al., 2016). Dogs of medium to large size with morphology specialized for hunting, guarding, coursing, or fighting existed from the late Iron Age onward (Luttschwager, 1965; Clark, 1995, 2012; Baxter, 2002; Baxter \& Nussbaumer, 2009; Phillips et al., 2009; Baxter, 2010 a, b; Bennett et al., 2016; Bennett \& Timm, 2016). Small dogs of less than $30 \mathrm{~cm}$ calculated shoulder height are known from several Iron Age sites in Britain-Baldock (Clark, 1995), Danebury (Grant, 1984), Salisbury Plain (Clark, 2006, in press), and Skeleton Green (Ashdown \& Evans, 1981), but note that the majority of these are dwarfs with limb bone indexes higher than 8 rather than gracile harriers or miniatures. Small dogs are frequent in Roman-era sites; Clark (2012) notes that they are present on $13 \%$ of Roman-era sites of rural character and 23-24\% of Roman-era sites of urban character, including forts. Again, most of these are dwarfs but Redlands Farm (Davis, 1997), Thistleton (Baxter, 2010b), and Winchester (Maltby, 1987), along with Heidelberg-Neuenheim in Germany (Luttschwager, 1965) and the dog catacombs at Saqqara, Egypt (Ikram, pers. comm.), produce miniatures. The smallest Roman-era dog published to date has an estimated shoulder height of only $21 \mathrm{~cm}$ and is a miniature from the Car- thaginian cemetery at Yasmina (MacKinnon \& Belanger, 2002). Clark (in press) reports an Iron Age miniature from Silchester which may be even smaller.

Distinctive backsloping occiputs and overall gracility make skulls of Vindolanda harriers easy to recognize. Smaller skulls with forward-sloping ("tucked-under") occiputs from the site (Plates VI, VII) are more problematic. They are similar to two other skulls: one is a Romano-British specimen from Linton in Cambridgeshire discussed by Baxter (2010a) and characterized by him as "Type $1 \mathrm{~b}$ " representing a female dwarf hound (Figure $8 \mathrm{~F})$. The other is a recent dog (FMNH 86832, Plate X) collected near Baghdad, Iraq by Charles A. Reed while he was in the country during the early 1960's as part of the Prehistoric Iraq-Jarmo Expedition mounted by the University of Chicago Oriental Institute and Field Museum of Natural History (Reed, 1961; Turnbull \& Reed, 1974; Lawrence \& Reed, 1983). Appreciable sexual dimorphism appears to be characteristic of dwarf hounds, putative females having low sagittal and lambdoidal crests and lacking the extreme bowing of limb elements displayed by males (Baxter, 2010a). However, although they are of nearly identical size, Reed's dog from Baghdad is more similar to the smallest dog skulls from Vindolanda than is the Linton skull, which has a more rugged cranium with thicker bone, less "step" in the facial profile, and a less bulbous braincase. Since there is no reliable way to tell dwarf hounds from miniatures without associated limb elements, it is nonetheless possible that all three of these crania represent female dwarf hounds.

It is significant that all the dogs we find to be most similar to the Vindolanda sample belong to old breeds (Reed's Baghdad dog, Spitz, Dachshund) or else breeds thought to have originated within a short geographic distance from the Vindolanda site (Patterdale/Lakelands/English Terrier, Scottish Terrier). It should also be borne in mind that a dog breed may "originate" in a given area as the result of importation of bloodstock to that area. Reed's collection of Middle Eastern dogs includes several distinct types varying from small to large in size. They are of nameless breed but nonetheless of ancient ancestry, for they derive at least in part from the ancient drift of trade along the Silk Road (Reed, 1969, 1983)-and as we show in an upcoming report, the small Baghdad dog is not the only one in Reed's col- 


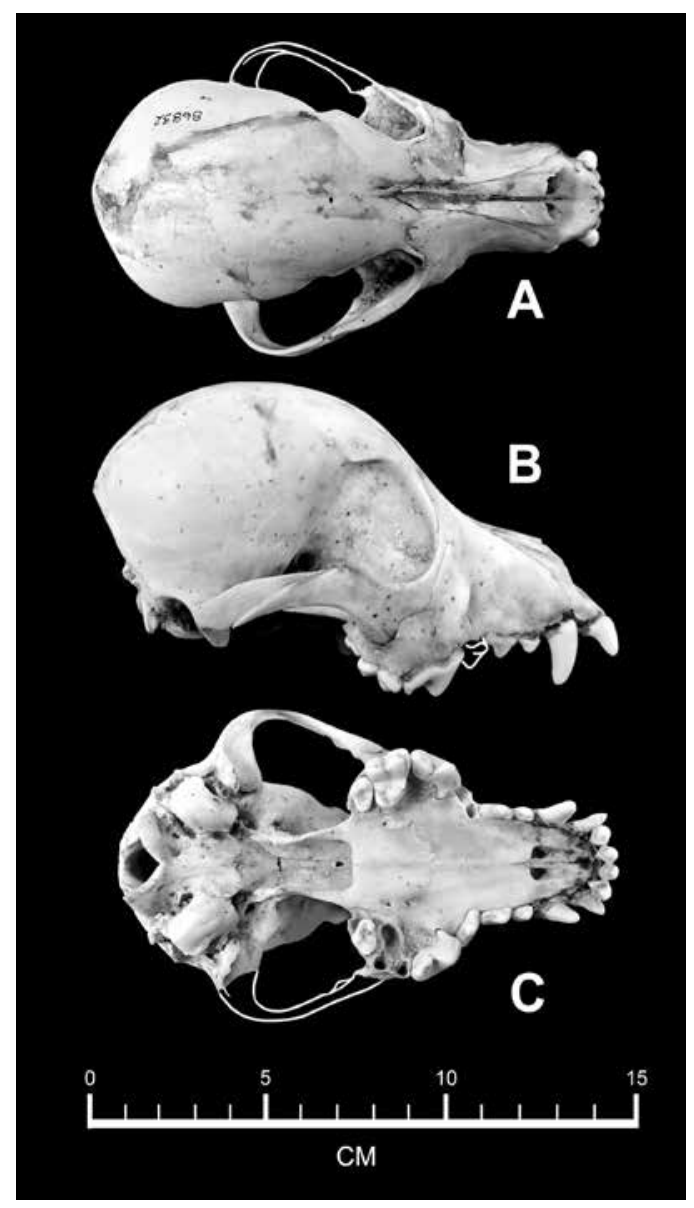

PLATE X

Recent domestic dog skull from near Baghdad, Iraq, FMNH 86832. A, dorsal; B, lateral; C, ventral views with minor restoration.

lection that closely matches a Vindolanda specimen (Bennett \& Timm, in prep). That Vindolanda dogs may ultimately have been sourced from areas bordering the Silk Road is conceivable, as the trading reach of the Roman Empire was enormous (Reed, 1969, 1983; Clark, 2012; Bennett \& Timm, 2016).

\section{Juvenilization in the Basicranium}

Juvenilized dog skulls demonstrate failure of certain elements of the basicranium to grow. In young puppies of all the canid species studied, the junction between the presphenoid, palatine, and pterygoid (PPP junction, Figure 3) is located anterior to the posterior lip of the palate. In Red foxes, coyotes, and wolves and in non-juvenilized domestic dogs, the presphenoid (and the vomer anterior to it) begin to lengthen soon after birth, pushing the PPP junction rearward. The amount of rearward movement is reflected by the magnitude of the dimension Px.

As growth proceeds, all the bones of a puppy's skull push on each other, but the first bones to form are those of the endochondral basicranium (Goodrich, 1958); they thus tend to dictate shape change with age. The longer and narrower the skull is destined to become in a given canid species, the earlier the PPP suture emerges from the cover of the palate, and the farther behind the palatal lip it eventually comes to lie. Thus, the PPP suture in a fox kit lies farther posterior than that of the coyote, wolf, or domestic dog at similar stage of tooth eruption (Figure 6), just as it also lies farther posterior in the adult.

The later-forming dermal bones, especially the frontal, lengthen to accommodate growth in the basicranium. This in turn elongates and flattens the head, diminishing the puppy-like "step" in the forehead and forcing the orbits into a shallower, less forward-facing orientation. Lengthening of the skull narrows the broad face of puppyhood; if the basicranium lengthens, the only way to retain a broad, puppy-like face is to build an overall larger dog (this is described by Drake (2004) as "proportioned dwarfism," but note her use of the term "dwarf" means "technically paedomorphic" and does not connotate chondrodysplasia).

Our algorithm $(\mathrm{Px} \times 100) / \mathrm{CP}$ quantifies the degree of juvenilization in dog skulls. Figure 5 contrasts North American Wolf, Indian Wolf, Australian Dingo, and New Guinea Singing Dog with 29 modern dog breeds, the total measurable sample of Vindolanda skulls, and four skulls of small Roman-era dogs not from Vindolanda. Breeds that fall below a score of 45 on this chart-Maltese, Chihuahua, Pekingese, Cavalier King Charles Spaniel, Japanese Chin, Griffon Brusselois, and Pug - we consider juvenilized. Some English Bulldogs are also juvenilized; the morphological range of this breed spans the gap between juvenilized types and the non-juvenilized skulls of the "primitive" outgroups.

The most important finding from our analysis is that the skulls of many small breeds of dog (for 
example, Yorkshire Terrier) are no more juvenilized than those of Dingoes; smallness, therefore, is not a predictor of juvenilization. Neither, however, are all juvenilized modern dogs small (for example, English Bulldog). None of the Vindolanda dogs is much juvenilized, though all those reported here are smaller than any Dingo or wolf. Although due to specimen breakage, Px must be estimated for some of the other Roman-era specimens for which good published photographs of the ventral aspect of the skull are available, we consider it unlikely that any of them fall into the range covered by juvenilized modern dogs. The Yasmina skull - smallest dog known from the Roman era - falls within the size range for the Maltese (MacKinnon \& Belanger, 2002), but nonetheless Px for this dog is likely greater than in the modern Maltese.

\section{General Morphological Features}

(1) Cranial index (Cephalic index or "Head Shape Index": $(\mathrm{ZW} \times 100) / \mathrm{BL}$, Figure 9). Small Vindolanda dogs fall into about the same range as North American wolves; interestingly, they are shorter-headed (or broader-faced) than both the Australian Dingo and the Indian wolf. In this (and other MTAs), the Vindolanda sample consistently plots with certain modern dogs (Group 1, Figures 9-17). This group includes the Patterdale (English or Lakelands) Terrier, Spitz, Dachshund, English Water Spaniel, and Scottish Terrier. The Vindolanda dogs also consistently plot with the New Guinea Singing Dog (NGSD). This is of interest because NGSDs are thought to have been present in New Guinea before 2000 BCE (KohlerMatznick et al., 2003) - in other words they and the Vindolanda sample both give us a window into dog diversification as it stood at that time.

(2) Snout length $($ NA $\times 100 /$ BL; Figure 10). Harcourt (1974) considered this to be nearly as valuable in differentiating dogs as the cranial index. According to our analysis however, the small dogs of Vindolanda are in this feature merely smaller-sized versions of the North American wolf, and similar to the NGSD. The range of snout length in Group

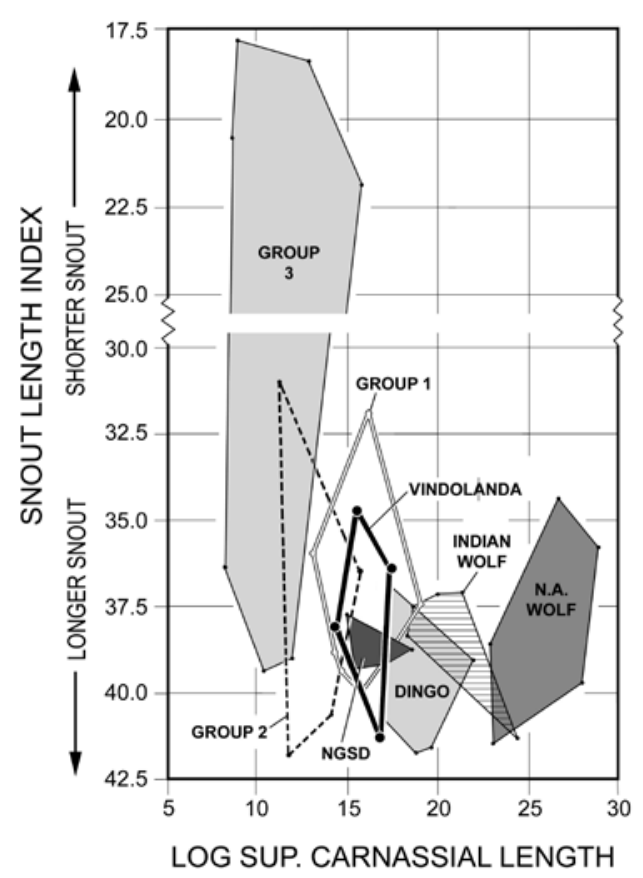

FIGURE 10

Harcourt's (1974) Snout length index $(\mathrm{SW} \times 100) / \mathrm{BL}$ rendered as an MTA.

3 dogs is large and is a measure of the effect of recent breeder selection.

(3) Snout width $(\mathrm{SW} \times 100 / \mathrm{NA}$; Figure 11). By this measure, the Vindolanda dogs are almost entirely disjunct from any wild or feral dog. They plot with the Baghdad dog and other Group 1 dogs - although there is also considerable overlap with Group 2 dogs. The latter group includes some old breeds such as the Lhasa Apso and Mexican Hairless, but is mainly composed of small terriers of relatively recent origin, such as the Yorkshire, Skye, and West Highland. This is significant because it suggests that skull shape can converge - and does so relatively quickly - as the result of intense selection by breeders.

\section{Analyses of Function}

In a previous paper (Bennett et al., 2016), we present indexes of functional significance (sug- 


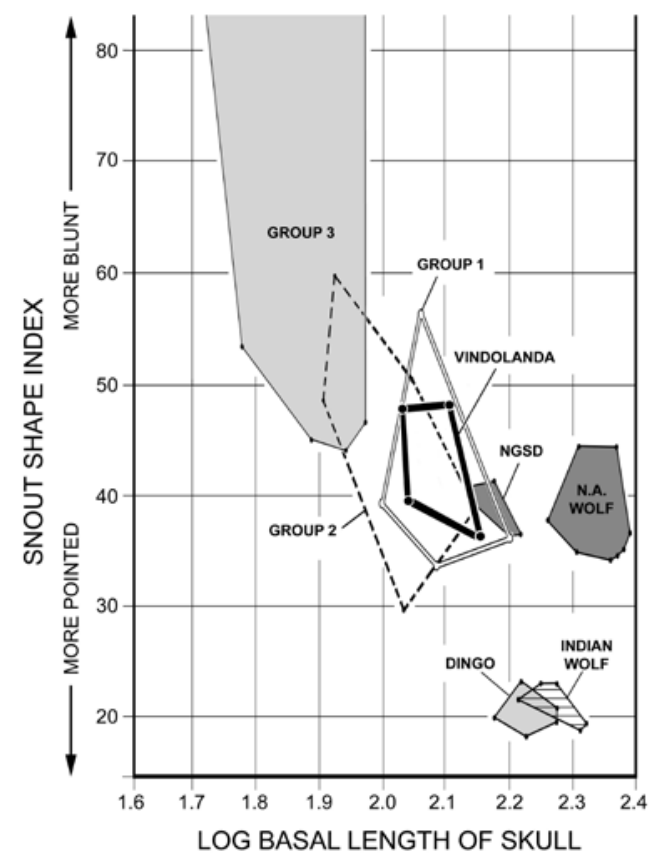

FIGURE 11

Snout width index $(\mathrm{SW} \times 100) / \mathrm{NA}$. The range of Group 3 dogs with respect to this measurement reaches upward to more than $140 \%$; we show only the lower part of the range.

gested by results of PCA), the most diagnostic of which are mouth shape, neck strength, and grip strength. The relationship of klinorhynchy (the downward angling of the snout, see Nussbaumer, 1982; Phillips et al., 2009) in dictating the shape of the jaw ramus is also important. Although these skull features are of great functional significance in wild and feral canids, it is not clear in all cases that breeders have primarily, or even deliberately, selected for greater hunting prowess or masticatory efficiency in small domestic dogs. Shape changes that arise among wild and feral canids, because they have functional significance, may originate in small domestic dogs as pleiotropic side effects of selection for juvenile appearance.

(1) Mouth Shape ((SW × 100)/PL; Figure 12). By this measure, the Vindolanda sample largely overlaps the NGSD, less so the Australian Dingo and Group 1 and Group 2 dogs. Once again, the range of Group 3 dogs far exceeds that of ancient dogs.

(2) Neck Strength $((\mathrm{RA} \times 100) / \mathrm{PL}$; Figure 13). This ratio is a measure of the dog's ability to

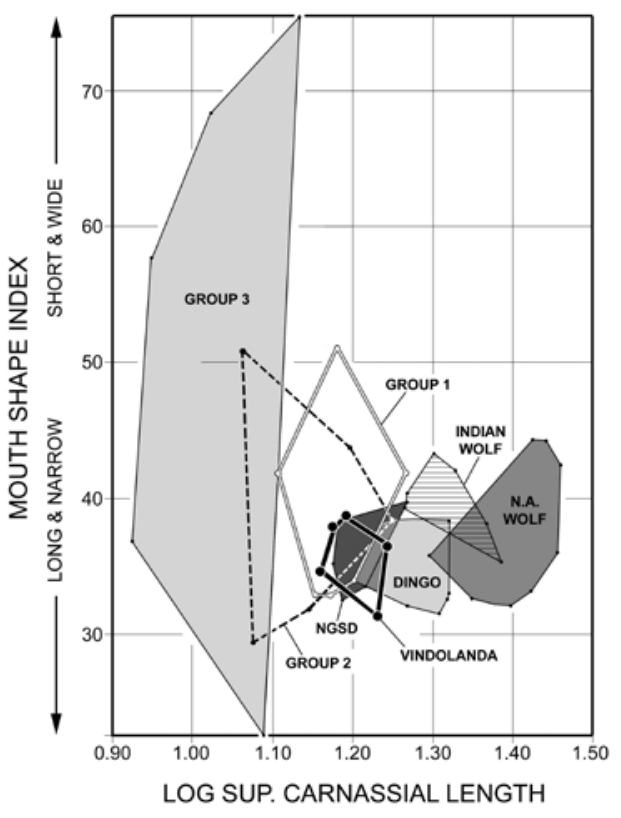

FIGURE 12

Mouth shape index $(\mathrm{SW} \times 100) / \mathrm{Pl}$.

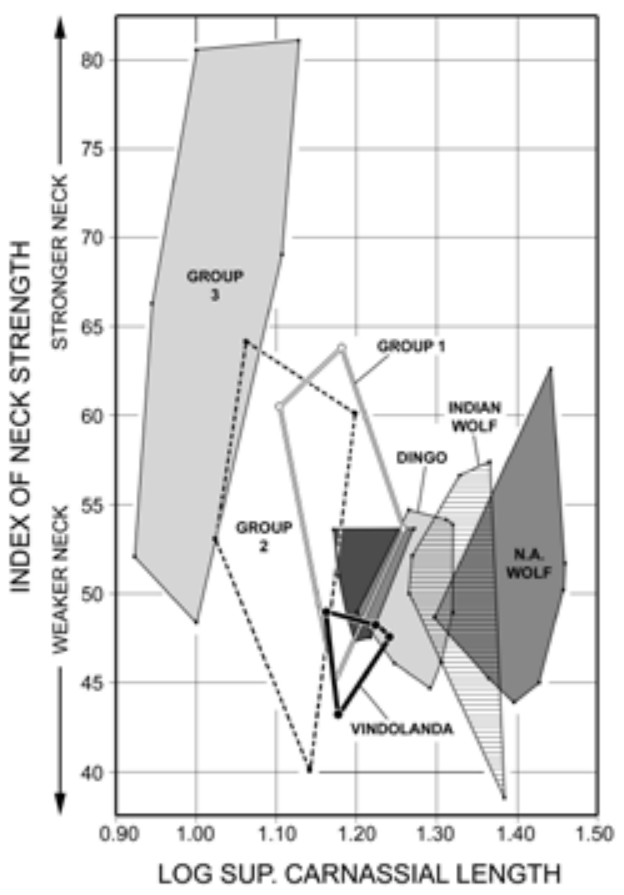

FIGURE 13

Index of neck strength $(\mathrm{RA} \times 100) / \mathrm{Pl}$. 
control large or wriggling prey. Our analysis shows that the small dogs of Vindolanda have necks that are only moderately strong in proportion to their size, as expected especially in harriers whose function is pursuit. Terriers by contrast have deliberately been bred to have strong necks and strong jaw grip, because their function is to pull prey out of burrows. In the smallest domestic dogs, however, a wide occiput can be a side effect of skull bulbosity. This is an interesting example of a chain of pleiotropic effects - breeder selection for miniaturization and juvenilization produces skull bulbosity, which in turn alters the proportions of the occiput, creating greater neck strength as an accidental benefit.

(3) Grip Strength $((\mathrm{CW} \times 100) / \mathrm{TL}$; Figure 14). This analysis reveals that the small jaw rami comprising the Vindolanda sample tend toward greater grip strength than wolves or Dingoes, similar to the NGSD. The observed range of Group 3 dogs is less here

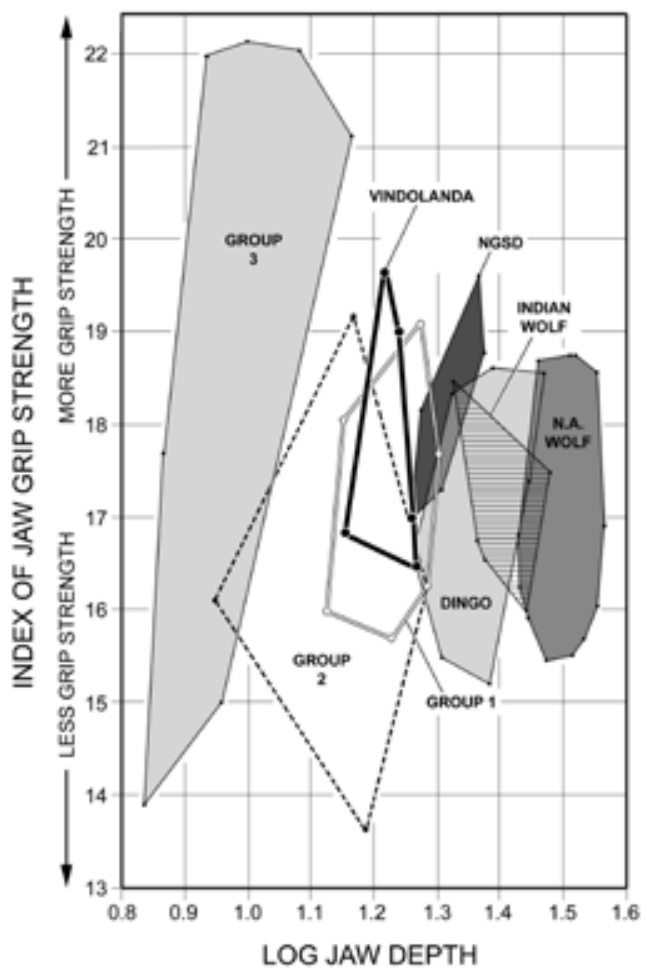

FIGURE 14

Index of jaw grip strength, calculated as $(\mathrm{CW} \times 100) / \mathrm{TL}$. than in other functional measures, an indication that breeders have not paid much attention to creating stronger grip in the smallest dogs.

(4) Relationship of $H B$ to Slope of the Occiput. Bennett (1980) introduced the idea that the antero-posterior length of the squamous temporal bone can be used to differentiate asses (Equus asinus), onagers (E. onager, E. kiang, E. hemionus), and one of the three species of zebra (E. zebra) from horses $(E$. caballus). The width of the squamous temporal, which fills the gap on the lateral surface of the skull between the glenoid process and the petrosal, is coordinate with the length of the posterior basicranium (HB). When HB is long, the squamous temporal is broadly exposed and the condyles are simultaneously pushed backwards, thus creating a backsloping occiput. When HB is short, the opposite obtains and the occiput is forward-sloping so that the occipital condyles are tucked under the lambdoidal crest. The amount of occipital slope varies within the domestic horse population from a few degrees of forward slope to as much as $30^{\circ}$ of backslope.

This functional complex is also a feature of the dog skull (Clark, 2012), and a backsloping occiput has similar functional consequences in dogs as horses - the more backsloping the occiput, the longer the atlas and axis tend to be, and the more open the resting angle between the skull and the neck bones from the third cervical downwards, yielding a more wide-open throatlatch, which is particularly evident when the animal is running (Figure 21). The only modern dogs that have backsloping occiputs are socalled "sight hounds," all of which are bred for cursoriality. Since in mammals inspired air must pass through the pharynx before it can get to the lungs, a wide-open throatlatch is of obvious functional advantage to a dog intended for chasing game.

(5) Relationship of Backsloping Occiput to Klinorhynchy. The relationship of occipital back-slope to klinorhynchy becomes evident when we consider dogs that have the most strongly tucked-under occiputs, which are highly klinorhynchic terriers. Sighthounds by contrast typically exhib- 
it low degrees of klinorhynchy. Terriers are not bred for cursoriality but for proportionally great strength throughout the body and particularly in the neck and jaws. While some of them (for example the Jack Russell Terrier, Figure 21B) are speedy, their running style is bouncy rather than long-striding, and at high speed the dog holds its head and neck in a manner noticeably different from that of sighthounds. While the head and neck conformation of the sighthound makes it most comfortable for the dog to aim its gaze as well as its snout straight forward, terriers universally run with their snouts angled downward and their eyeballs rolled to some degree upward in the sockets. We consider the several small skulls from Vindolanda that have backsloping occiputs to be ancient sight-hounds of small size, morphologically similar to the modern Pharaoh hound (a recent product of crossbreeding), or the African Isiq'ha (a breed reportedly introduced to North Africa by the Romans and which may well be closely related to the Vindolanda sight-hounds; Hall, 2000) (Figure 19, Plates I-V, and see Bennett \& Timm, 2016, figures 12-14).

(6) Klinorhynchy and Jaw Shape (Plates XIXII). We do not quantify this feature but provide comparative examples. The shape of the jaw ramus is a direct consequence of the degree of klinorhynchy in the skull. In airorhynchic dogs (those whose snouts and palates angle upward relative to the line of the basicranium) and those with low degrees of klinorhynchy, the jaw ramus is curved ("rockered"). In dogs with greater klinorhynchy-more downsloping snouts-the jaw rami are straight or even bent downward at the anterior end ("chinned"). The range of klinorhynchy among small Vindolanda dogs is from 2.4 to 17.5 degrees. The lower figure is found among the Vindolanda sample of small sight-hounds; klinorhynchy approaching the higher figure is found in Romano-British dogs resembling the one from Linton, as well as the smallest nearly complete Vindolanda dog (V07-87A 9819), which presents a degree of klinorhynchy approaching that of the Scottish Terrier.

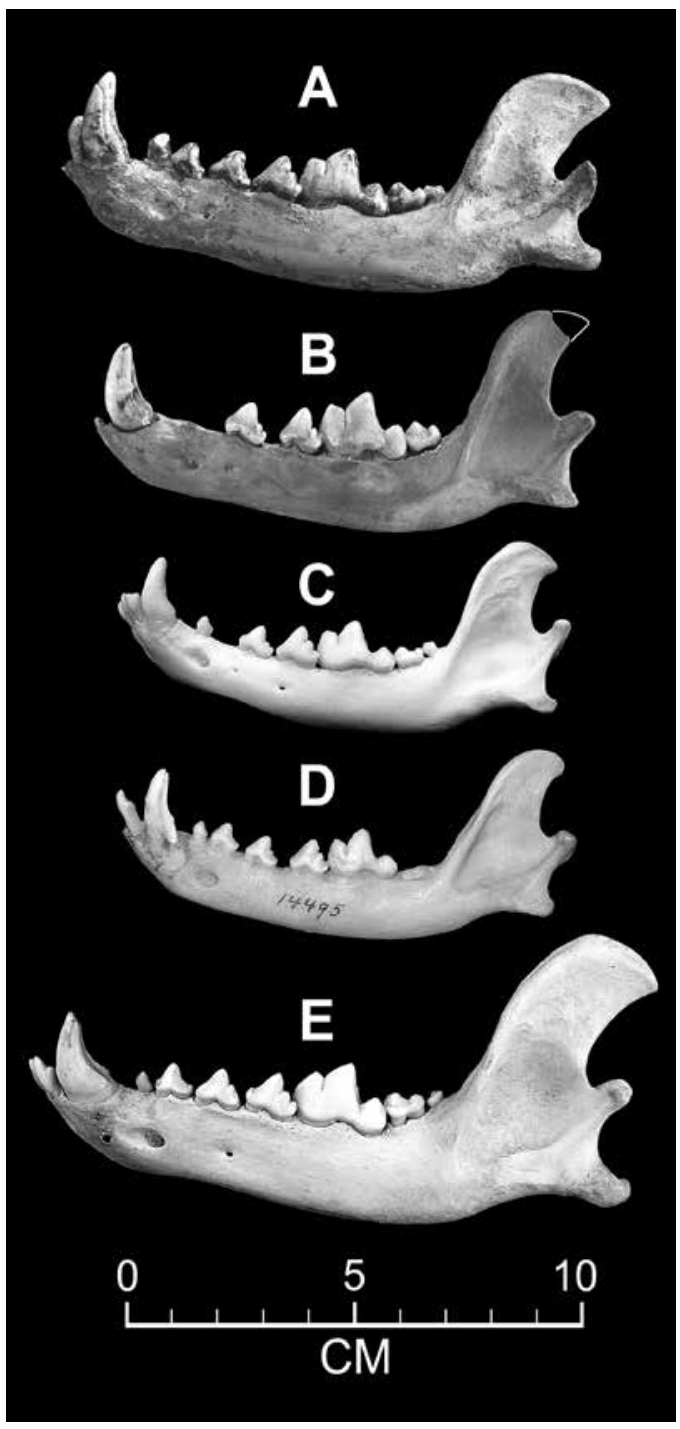

PLATE XI

"Chinned" dog jaw rami, to scale. A, Vindolanda E93-112 3188 with $\mathrm{TL}=116.09 /$ matching a skull with calculated $\mathrm{BL}=139$ mm. B, Vindolanda V07-68A 7396 with $\mathrm{TL}=100.10 /$ calculated $\mathrm{BL}=120.6 \mathrm{~mm} . \mathrm{C}$, Spitz SKU 1500 with $\mathrm{TL}=98.63 /$ actual BL $=119.46$ mm. D, Skye Terrier AMNH 14495 with TL = 98.88/ actual BL $=112.97 \mathrm{~mm}$. E, Scottish Terrier LACM 30541 with $\mathrm{TL}=131.81 /$ actual $\mathrm{BL}=160.47 \mathrm{~mm}$. Note the crowding of $\mathrm{P} 4$ against M1. Compare Figure 20A-D, another "chinned" ramus.

\section{Pleiotropic Effects of Miniaturization}

The skulls of dogs smaller than a threshhold of about $40 \mathrm{~mm}$ in brainstem-base length (HB) (Huber, 1974) - which translates to about $140 \mathrm{~mm}$ in basal length (BL; Figures 2, 3)-typically show a 


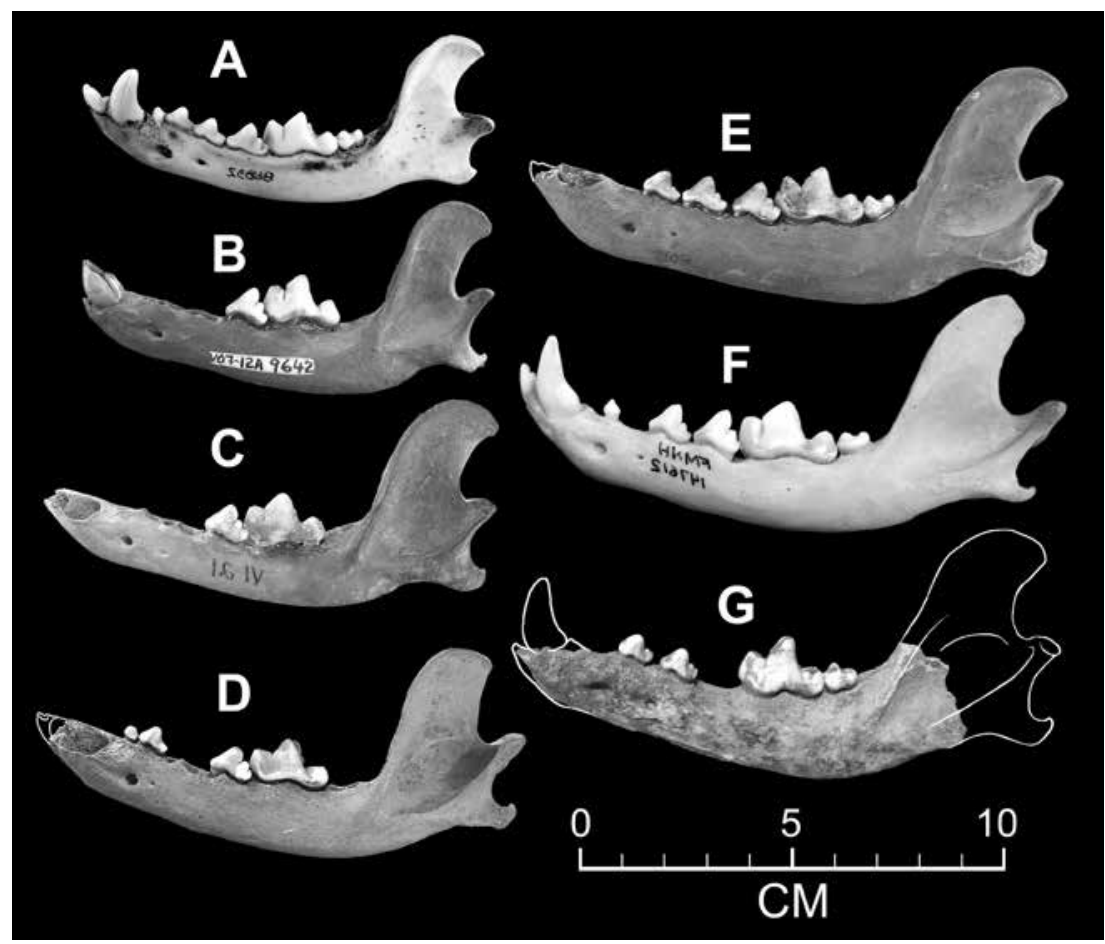

PLATE XII

Slightly to moderately "rockered" dog jaw rami, to scale. A, Small dog from near Baghdad, Iraq FMNH 86832 (reversed), with TL= 95.59/actual BL $=115.07 \mathrm{~mm} . \mathrm{B}$, Vindolanda V07-12A 9642 with $\mathrm{TL}=96.38 /$ calculated $\mathrm{BL}=116.12 \mathrm{~mm} . \mathrm{C}$, Vindolanda VI-21 2061 with $\mathrm{TL}=107.74 /$ calculated $\mathrm{BL}=129.80 \mathrm{~mm}$ (reversed). D, Vindolanda II85-E7A 2136 with TL $=117$ (estimated) $/$ calculated BL $=$ approximately $140 \mathrm{~mm}$. E, Vindolanda G(M) 10159 with $\mathrm{TL}=120.53 /$ calculated BL $=145.57 \mathrm{~mm} . \mathrm{F}$, Patterdale (English or Lakeland) Terrier FMNH 147612 (reversed) with TL = 127.50/actual BL = 113.01. G, Vindolanda V06-51A (reversed) with TL = 130 (estimated)/ calculated BL approximately $155 \mathrm{~mm}$. Note crowding of P4 against M1 in A-F, and antemortem loss of P4 in dog G.

suite of characteristics traditionally thought to be associated with paedomorphy: bulbous cranium, sagittal and lambdoidal crests weak or absent, and relatively large orbital diameter. They also frequently show "keyholing" or failure of the dorsal lip of the foramen magnum to completely ossify. We consider all of these to be sequelae not of paedomorphy (and not of juvenilization), but merely of miniaturization: since most dogs that display them do not show shortening of Px, they cannot be the result of juvenilization. Dwarf (chondrodystrophic) dogs (i.e., English Bulldogs, Pugs, Dachshunds, Welsh Corgis), which have much heavier and less bulbous skulls even when BL is nearly as small as the dogs examined in this report, usually also fail to show these features.

(1) Bulging Cranium ("Tweetiebird" Index $(\mathrm{CW} \times 100) / \mathrm{RA}$, Figure 15): The Vindolanda dogs broadly overlap both Group 1 and NGSD, and this is one of the few instances in which they overlap Group 3 (this group includes the smallest modern dogs and those with the most extremely juvenilized skulls). As the size of the dog diminishes, the degree of cranial bulging tends to increaseapparently because the dog brain does not miniaturize at the same rate as the skull, or, in other words, small domestic dogs have brain volume and weight larger than expected for their body weight (Röhrs, 1985; Kruska, 1988; Zeder, 2012). No Vindolanda dog shows as bulging a cranium as the most extreme modern dogs, but our analysis shows a definite difference from the putative primitive condition.

(2) Large Orbital Diameter Relative to Skull Length ("bugeye Index" (ODW × 100)/BL, Figure 16): The Vindolanda dogs approach modern dogs in possessing relatively large orbits, and the MTA plot demonstrates a 


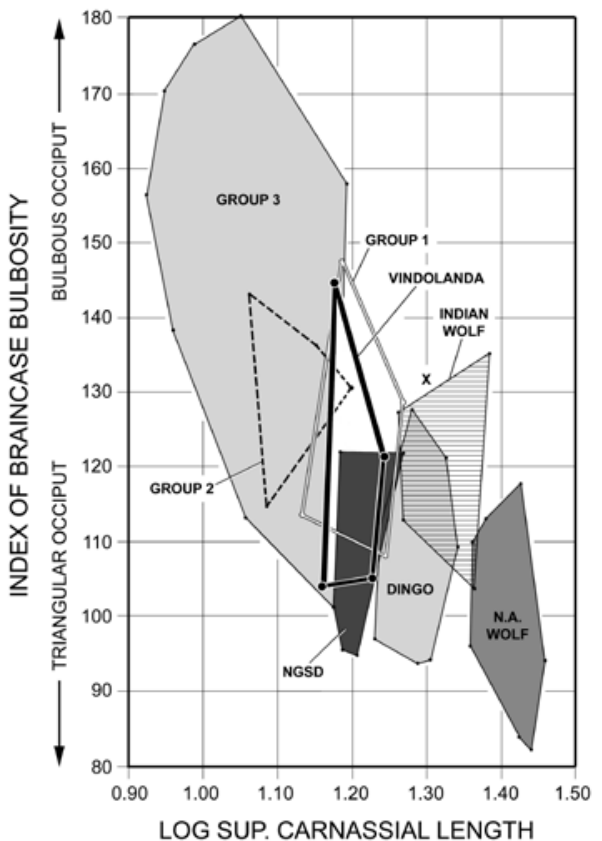

FIGURE 15

Index of braincase bulbosity ("Tweetiebird index"), $(\mathrm{BW} \times 100) / \mathrm{RA}$.

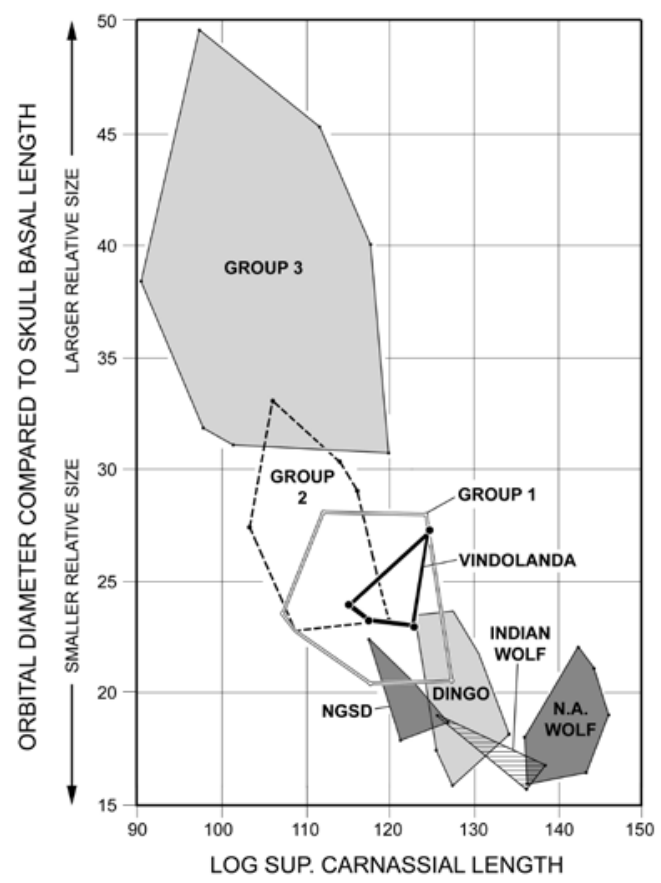

FIGURE 16

Index of orbital size ("bugeye index") (ODV X 100)/BL. nice progression from wild and feral canids to Group 3 dogs. The Vindolanda sample falls entirely within the Group 1 hull but is disjunct from all wild and feral canids. It is significant that orbital diameter that is large in relation to $\mathrm{BL}$ is almost exclusively found in dogs below the $140 \mathrm{~mm}$ BL threshold. The eyeballs of these dogs are no larger in absolute dimension than those of larger dogs, which implies that-analogous to the situation with the brain - the dog eyeball does not miniaturize at the same rate as the skull, even under intense directional selection.

(3) Proportionally large carnassials (Figure 17, Plate XI-XII): Crowding of the superior dentition with twisting of the anterior premolars is characteristic of many brachycephalic domestic dog breeds. The vast majority of domestic dogs have carnassial teeth smaller than wolves (Bennett et al., 2016), and some have been selected for skull elongation; both factors allow teeth to be spaced out along the jaws. However, in small dogs - even those that are not particularly short snouted - the carnassial teeth

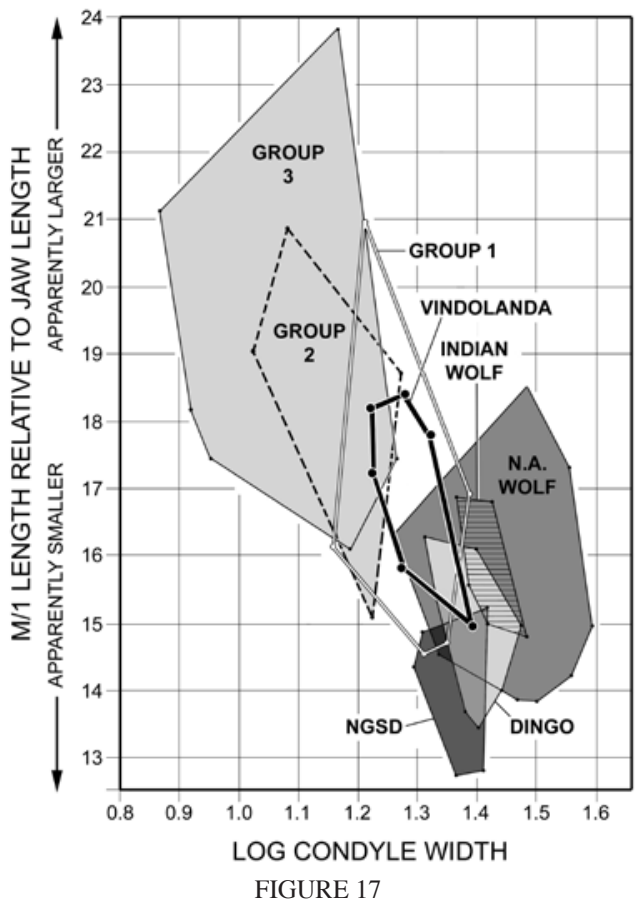

Relative size of inferior carnassial $(\mathrm{M} 1 \times 100) / \mathrm{TL}$. 
appear outsized because they have not miniaturized as much as the skull. Our analysis (Figure 17) shows that NGSDs have the smallest inferior carnassials relative to jaw length - and thus the least frequency and degree of tooth crowding, nondevelopment, or noneruption. The Vindolanda range is similar to that of the North American wolfbut see discussion below of noneruption in Vindolanda dogs. Modern dogs in Group 1 and Group 2 extend the range, with Group 3 as in other analyses reaching the greatest extreme.

(4) Occipital Bulging, Keyholing, and Fenestration (Figure 18): We do not quantify this feature but illustrate it for comparison. "Keyholing" is failure of the dorsal lip of the foramen magnum to fully ossify, while "bulging" denotes bulging of the occiput above the foramen magnum. "Fenestration" is failure of the embryonic sutures between the various ossification centers of the basioccipital to close. Where "Tweetiebirding" of the skull is great, keyholing is also likely to be extreme. Some modern Group 3 dogs show a huge slot-like "keyhole" that reaches upward nearly to the top of the occipital bone (Figure 18F). This is often accompanied by large fenestrations to either side. In such dogs, nearly $50 \%$ of the occipital plate may remain unossified throughout life. No Vindolanda dog shows these features to such extreme degree, but definite keyholing is present in several (Figure 18A, B, C). Keyholing is much more common in smaller dogs and in those with brachycephalic or mesocephalic skull proportions, while being rare among dolichocephalic dogs (Watson et al., 1989; Simoens et al., 1994; Onar et al., 2013).

All authors conclude that keyholing is a variation in normal developmental sequence rather than indicative of pathology. We agree that it should not be thought of as a pathology, but it is certainly abnormal. Keyholing has a functional cause and is not merely a chance variation. Since it is almost exclusively associated with small to medium body size and reaches extreme degree in tiny dogs, we prefer the idea that it arises because in small dogs, as above noted, brain volume is larger than expected for given body weight (Röhrs, 1985; Kruska,

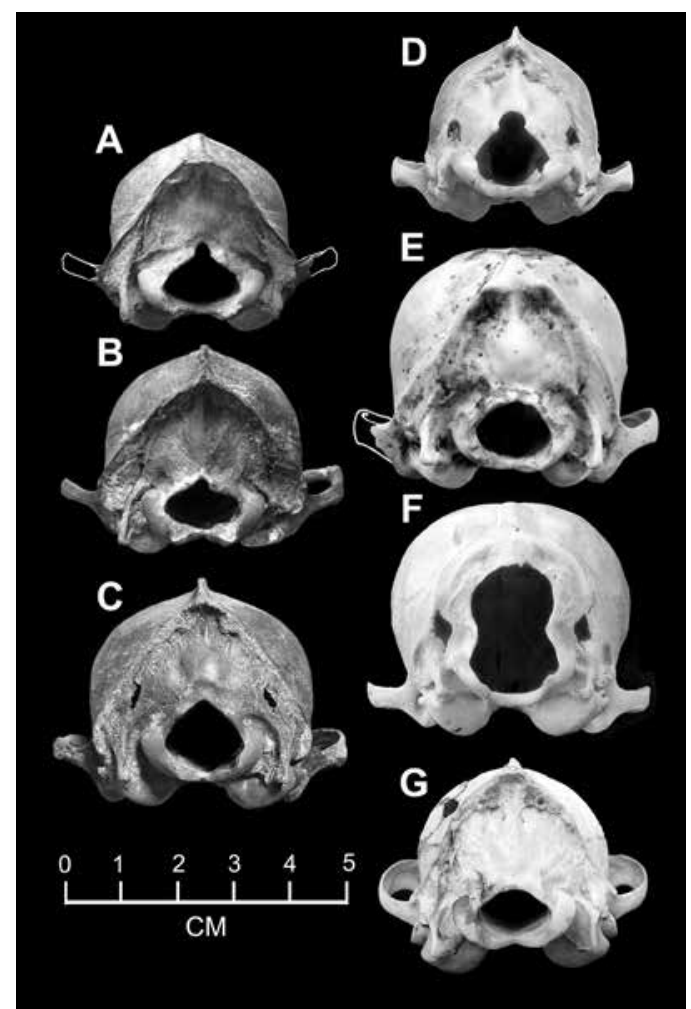

FIGURE 18

Keyholing, bulging, and fenestration. A, Vindolanda LXXIV $10153, \mathrm{BL}=110.06$, showing a moderate degree of keyholing but little bulging and mastoid foraminae which are of normal size and shape; B, Vindolanda VI-24 19872, BL = 118.76, showing minor keyholing, no bulging, normal mastoid foraminae; $\mathrm{C}$, Vindolanda V07-87A 9819, BL $=107.68$, showing slight keyholing and small fenestrae, that is, enlargement of the mastoid foraminae; D, Patterdale (English or Lakeland) Terrier FMNH 147612, $\mathrm{BL}=113.01$, showing marked keyholing, moderate bulging, and moderate fenestration; E, small dog from near Baghdad, Iraq FMNH 86832, BL $=105.07$, showing bulging of the occipital plate but no keyholing and normal mastoid foraminae; F, Griffon Brusselois LACM 30636, BL $=63.35$, with extreme keyholing and large fenestrae; G, Red fox KU 85466, BL $=137.99$, showing braincase bulbosity about equal to A, B, or D, but no keyholing, bulging, or fenestration.

1988; Zeder, 2012). Where "Tweetiebirding" is not sufficient to accommodate the brain, room can be created by bulging of the occiput above the foramen magnum. In some cases, backwards pressure is evidently enough to inhibit ossification, in which case a keyhole develops. Fenestrations to either side of the foramen magnum act to provide further relief.

In tiny dogs, fenestrations between dorsal skull elements frequently occur also. This 


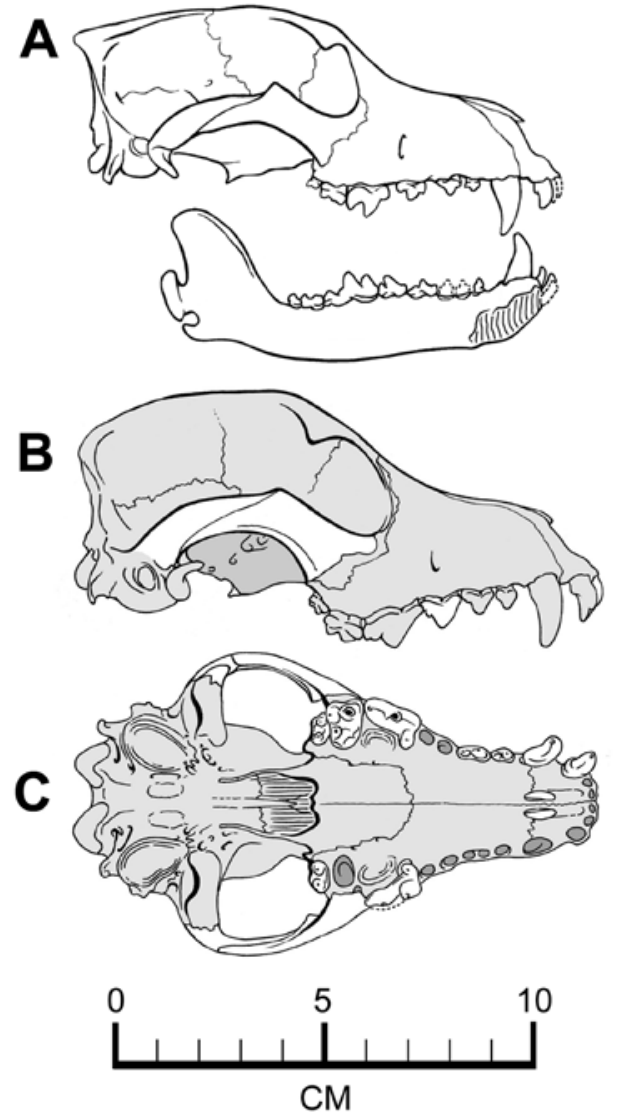

FIGURE 19

A, modern Isiq'ha Hound (drawing by author Bennett from a photograph in Hall, 2000); right lateral view of skull and left jaw ramus (note scale is approximate). B, C, restorations by author Bennett of Vindolanda harrier specimen LXXIV 10153. B, right lateral view; $\mathrm{C}$, ventral view (reversed). Minimal rugosity and cresting, relatively thin bone, distinct facial "step," and backsloping occiput distinguish this functional type. See Plate 4 for the actual specimen.

phenomenon suggests that selection for extreme miniaturization could "accidentally" produce a skull in which the brain is covered only by a patchwork of disjunct bony plates. That keyholing is a side effect of small body size and not of juvenilization is corroborated by the fact that a bulging cranium is present in Red foxes (Figure 18G).

(5) Noneruption or early loss of anterior premolars (Figure 20): We present X-ray images of the jaw of a puppy and of a miniature from Vindolanda. The puppy (Figure $20 \mathrm{E}-\mathrm{H}$ ) belongs to a type of dog that would

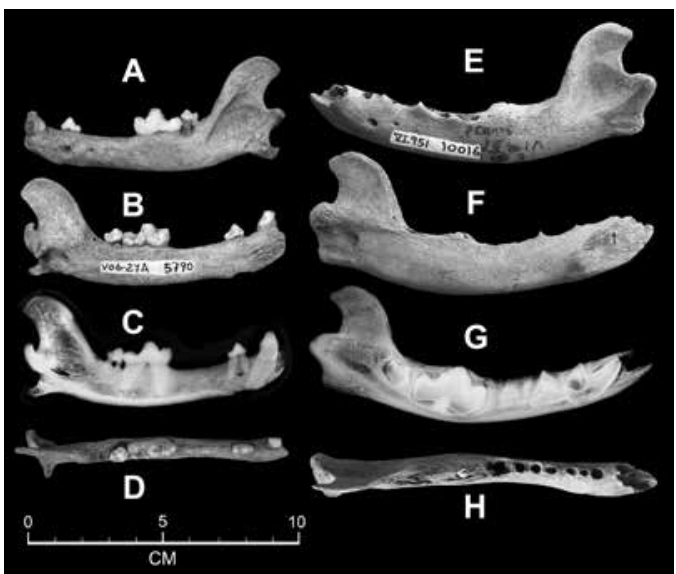

FIGURE 20

X-ray studies of small dog jaw rami from Vindolanda, to scale. A-D, showing pre-mortem loss of most of the anterior premolars and complete infilling of the alveoli (Vindolanda V06-27A 5790). The teeth are heavily worn, suggesting that the dog had probably lost the teeth years before its death. X-ray (view C) of the same jaw shows no developing or unerupted teeth within. $\mathrm{TL}=96.4 \mathrm{~mm}$ (which would match a skull with calculated BL of $116 \mathrm{~mm}$ ). E-H, the jaw of a puppy of a large dog (VI-951 10016). Though all the deciduous teeth were lost during excavation, X-ray study (view $\mathrm{G}$ ) reveals a full complement of unerupted adult teeth within the jaw. TL $=128 \mathrm{~mm}$.

have a mature skull BL of greater than 140 $\mathrm{mm}$; it is not a miniature. Although none of the puppy's deciduous teeth were recovered during excavation, X-ray (Figure 20G) reveals that the jaw contains the full normal complement of unerupted permanent teeth. By contrast, X-ray of the miniature dog's ramus (Figure 20C) reveals no teeth within. The permanent teeth of this dog are heavily worn, and examination of the dorsal aspect of the ramus reveals a "seam" of secondary bone, the last remnant of the infilling of the row of empty alveoli. This suggests that the dog lost the missing anterior premolars years before its death. Alternatively, it is possible that tooth buds for one or more anterior permanent premolars never form. $\mathrm{X}$-ray studies of mature dogs cannot differentiate between early loss and nondevelopment/noneruption. Early loss occasionally occurs in medium and large-sized dogs as well as in wolves, but in these individuals tooth loss is typically one-sided and there is often accompanying evidence of trauma or disease. 

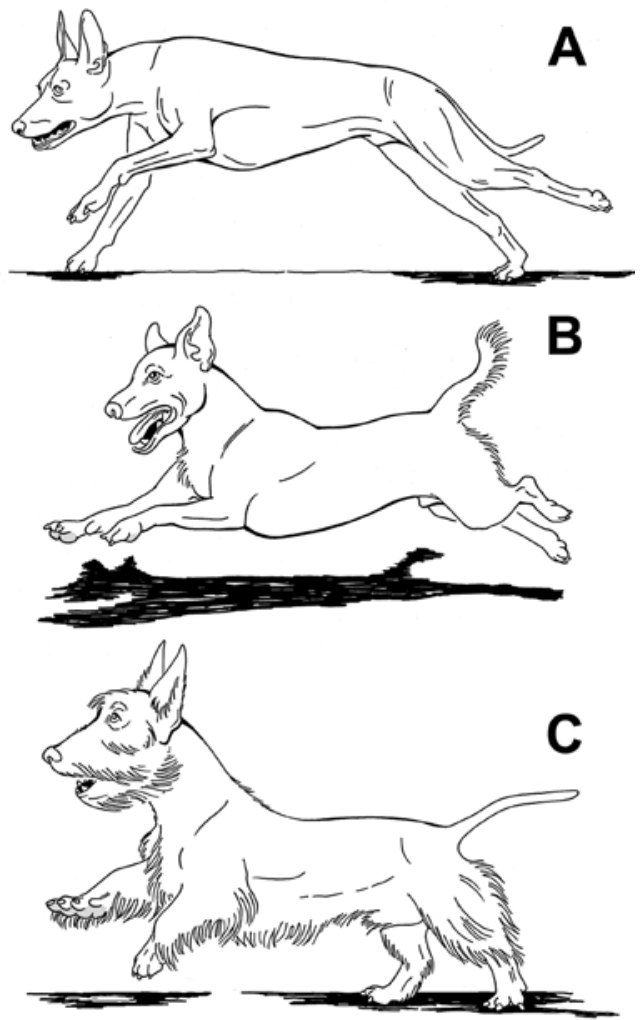

FIGURE 21

Head posture during fast locomotion in sighthounds vs. terriers. A, Pharaoh hound, a type of harrier. B, Jack Russell Terrier. C, Scottish Terrier. The terriers hold their necks more erect with a more acute angle between neck and skull.

\section{CONCLUSIONS}

The small, gracile Vindolanda dogs examined in this report are incipiently juvenilized, as are similar dogs from other Romano-British and Roman-era sites, but it is not possible to tell whether any of them are paedomorphic and we suggest that the term "juvenilized" be substituted in future dog research for "paedomorphic".

Although they are smaller than either Dingoes or North American or Indian wolves, the small dogs of Vindolanda have skulls hardly more juvenilized than Dingoes. We think that skull juvenilization, like miniaturization, began during the Roman era, but the advent of marked skull juvenilization in dogs, such as is characteristic of many modern breeds, appears to have occurred after the fall of the Roman Empire in about 415 CE. The small dogs from Vindolanda consistently cluster with Dachshund, English Water Spaniel, Patterdale Terrier, Scottish Terrier, Spitz, and the small dog from Baghdad. Note that these are all old breeds, and many hail from areas close to Vindolanda in Scotland or northern England. Similarities to the Baghdad dog are probably not coincidental, in view of the great trading reach of the Roman Empire (see discussion in Bennett \& Timm, 2016).

Some researchers have concluded that juvenilization and/or paedomorphy are not characteristic of the earliest domesticates such as goats (Zeder, 2006, 2012), but juvenilization appears eventually to affect all domesticates (Zeder, 2015). Small dogs certainly had functional significance in the communities within which they were bred. Clark (2012) suggests that small dogs may have been valued as rat predators and not merely as "lap dogs" or pets. Miniatures as well as dwarfs can be efficient "ratters": The American Kennel Club acknowledges Yorkshire Terriers, miniature Pinschers, miniature Schnauzers, Schipperkes, Affenpinschers, and even the tiny Griffon Brusselois as good ratters along with stouter and heavier dwarf breeds. Neither the Black Rat (Rattus rattus) nor the Norway Rat (Rattus norvegicus) have been found at Vindolan$\mathrm{da}$, but this is probably due to lack of wet-sieving over the site as a whole, since the Norway Rat is known from Roman London (Rackham, 1979), and Black Rat and several other common small mammal and bird species unlisted at Vindolanda have been recovered in 3rd-4th century levels at South Shields only a short distance away (Yalden, 1999). Wet-sieving carried out in the subfloor of the East Granary at Vindolanda produced abundant remains of both House Mouse (Mus musculus) and two species of wood mice (Apodemus) (Bennett \& Timm, 2013). Domestic cat (Felis catus) has been recovered from Vindolanda but is rare (Bennett, 2005, 2007); it thus seems likely that, whether rats were present at this site or not, small dogs fulfilled the role of "mouser."

The small dogs of Vindolanda, along with the other small Romano-British and Roman-era dogs studied, show a high frequency of failure to erupt/ loss of anterior premolars in the lower jaw, and thinness of the lower jaw. These are characteristic features of juvenilized dogs, and they are the characteristics in which small dogs of the Roman era most resemble small modern dogs. In other features the ancient dogs show only an incipient 
degree of juvenilization: their carnassials are proportionally somewhat larger than Dingoes, they are somewhat more "bugeyed" than Dingoes, they are shorter in face, muzzle, and snout than Dingoes, and they sometimes show keyholing affecting the shape of the foramen magnum, even though their braincases are not much more bulbous or "Tweetiebirded" than those of Dingoes.

Shape changes that arise among wild and feral canids because they have functional significance may originate in small domestic dogs as accidental side effects of selection for juvenile appearance. Thus, "Tweetiebirding," "bugeye," and disproportionately large carnassial teeth are likely pleiotropic effects of miniaturization (Zeder, 2012). They create anomalies -if not actual pathologies-in the development of the skull and in the morphology of the adult skull. This is because brain size, eyeball size, and carnassial tooth size are not controlled by the same genetic mechanism that drives skull miniaturization, so that the organs involved do not miniaturize at the same rate as the skull (Clark, 2012).

No known Roman-era dog has as small a Px as the most juvenilized modern dogs. With respect to this parameter, which we use as the main measure of juvenilization, the small dogs of Vindolanda are hardly more juvenilized than Dingoes, even though they are noticeably smaller than Dingoes and as small as some highly juvenilized modern dogs. In terms of Px, small dog skulls from Thistleton (1228, Baxter, 2010b) and other RomanoBritish sites appear to be no more juvenilized than the small dogs from Vindolanda. The same can probably be said of the tiny Yasmina dog, as well as of any of the smallest dogs from other late Iron Age and Roman-era sites, whether from Germany (Luttschwager, 1965), Pannonia (Bartosiewicz, 2000), Italy (Farello, 1995; De Grossi-Mazzorin \& Tagliacozzo, 2000), or Egypt (Churcher, 1963; Ikram, pers. comm.).

Two millennia ago, deliberate selective breeding had not long been practiced upon the domestic dog population, at least in Roman-influenced Europe, and small, gracile dogs are unknown in this geographic area until the late Iron Age. The history of dog domestication stretches back about ten thousand years; the propagation of miniature dogs occurs only after breeders realized the techniques of selection about 2100 years ago. Once this occurred, the degree of miniaturization and the frequency of miniature lineages have tended to increase rapidly.
This study shows that juvenilization lagged behind miniaturization, and that reduction in the parameter Px in small European dogs has increased through time. Today juvenilized strains can be found in most dog breeds, or the juvenilized bloodline itself may become recognized as a separate breed.

Our index of juvenilization, Px, is a simple yet powerful tool which we hope more researchers will employ in future studies of dogs.

\section{Institutional Abbreviations}

AMNH $=$ American Museum of Natural History, New York; AM = Australian Museum, Sydney; FMNH $=$ Field Museum of Natural History, Chicago; KU = University of Kansas Natural History Museum, Lawrence; LACM = Los Angeles County Museum of Natural History, Los Angeles; QSLD = Queensland Museum of Natural History, Brisbane; SKU = Museum of Osteology, Skulls Unlimited International, Oklahoma City; UNSM = University of Nebraska State Museum, Lincoln.

\section{ACKNOWLEDGEMENTS}

We gratefully acknowledge the financial support of the Vindolanda Trust. Andrew Birley and Justin Blake provided on-site assistance and useful discussion. Greg Campbell gave valuable advice on morphometrics and study design. Collection access was provided by Maria Eifler and Dave Burnham, University of Kansas Natural History Museum; Larry Heaney and Bruce Patterson, Field Museum of Natural History; Robert S. Voss, American Museum of Natural History; Heather Janetzky, Queensland Museum; Sandy Ingleby, Australian National Museum; James Dines, Los Angeles County Museum of Natural History; Jay Villemarette and Joey Williams, Skulls Unlimited, Inc.; and Tom Labedz, University of Nebraska State Museum. Scott Campbell and George Pisani, Kansas Biological Survey, provided excellent logistical support. Specimen photos and helpful discussion came from Ian Baxter and Mark Nussbaumer; they along with Kate Clark and Michael Fulford assisted us with literature acquisition. Salima Ikram (American University, Cairo) provided study photos of the Saqqara miniature dog. Special thanks 
to Sarah Taylor for the photos in Plate V and to John Chorn for providing excellent X-ray images. Hennie Van Konynenburg and Salvador Gonzales assisted with translation.

\section{REFERENCES}

Ashdown, R. \& Evans, C. 1981: Animal bones. Skeleton Green: A Late Iron Age and Romano-British site. Britannia Monograph 2: 205-235.

AzúA, R.V. 2000: Prehispanic dog types in Middle America. In: Crockford, S.J. (ed.): Dogs Through Time: an Archaeological Perspective: 193-204. Proceedings of the $1^{\text {st }}$ ICAZ Symposium on the history of the domestic dog. B.A.R. (International Series) 889. Oxford.

Bartosiewicz, L. 2000: Metric variability in Roman period dogs in Pannonia Province and the Barbaricum (Hungary). In: Crockford, S.J. (ed.): Dogs Through Time: an Archaeological Perspective: 181-189. Proceedings of the $1^{\text {st }}$ ICAZ Symposium on the history of the domestic dog. B.A.R. (International Series) 889. Oxford.

BAXTER, I.L. 2002: A dwarf hound skeleton from a Romano-British grave at York Road, Leicester, England, U.K., with a discussion of other Roman small dog types and speculation regarding their respective aetiologies. In: Snyder, L.M. \& Moore, E.A. (eds.): Dogs and People in Social, Working, Economic or Symbolic Interaction: 12-23. Oxbow Books, Oxford.

- 2010 a: Small Roman dogs. Alexandria Archive 901: 1-9. Available at http://alexandriaarchive.org/bonecommons/items/show/901.

- 2010 b: A re-examination of the Thistleton canids. Alexandria Archive 885: 1-11. Available at: http://alexandriaarchive.org/bonecommons/items/show/885.

BAXTER, I.L. \& Nussbaumer, M. 2009: Evidence of morphometric variation in an Iron Age dog cranium from Trumpington, Cambridgeshire, U.K. Archaeofauna 18: 69-78.

BenNetT, D.K. 1980: Stripes do not a zebra make, Part I: A cladistic analysis of Equus. Systematic Zoology 29: 272-287.

- 2005: Bone from the Severan ditch, Area A, 2004. In: Birley, A. \& Blake, J. (eds): The Vindolanda Excavations, 2003-2004. The Vindolanda Trust, Hexham, Northumberland: 115-157.

- 2007: Ongoing mammal bone research at Vindolanda: interim report on the 2005-2006 collections. In: Birley, A. \& Blake, J. (eds.): The Vindolanda exca- vations 2005-2006. The Vindolanda Trust, Hexham, Northumberland: 200-204.

BennetT, D.K. \& Timm, R.M. 2013: Microfaunal remains from the east granary, Roman Vindolanda: evidence for human-animal interactions. In: Birley, A. \& Blake, J. (eds): The Vindolanda Granary Excavations. Roman Army Museum Publications, Brampton, Greenhead: 72-98.

- 2016: The dogs of Roman Vindolanda, Part II: Time-stratigraphic occurrence, ethnographic comparisons, and biotype reconstruction. Archaeofauna 26: 93-112.

Bennett, D.; Campbell, G. \& Timm, R.M. 2016: The dogs of Roman Vindolanda, Part I: Morphometric techniques useful in differentiating domestic and wild canids. Archaeofauna 26: 71-92.

Birley, A. 2003: Vindolanda Research Report, 2003: The Excavations of 2002-2002, Volume I. The Vindolanda Trust, Bardon Mill. Hexham.

Blake, J. 2014: Vindolanda Research: the Excavations of 2007-2012 in the Vicus or Extramural Settlement ('Area B'). Roman Army Museum Publications, Brampton. Greenhead.

Churcher, C.S. 1993: Dogs from Ein Tirghi cemetery, Balat, Dakleh Oasis, Western Desert of Egypt. In: Clason, A.; Payne, S. \& Uerpmann, H.-P. (eds.): Skeletons in Her Cupboard: a Festschrift for Juliet Clutton-Brock: 39-59. Oxbow Monographs 34. Oxford.

ClARK, K.M. 1995: The later prehistoric and protohistoric dog: the emergence of canine diversity. Archaeozoologia 2: 9-32.

- 2006: The dog assemblage. In: Fulford, M.; Clarke, A. \& Eckhardt, H. (eds.): Life and Labour in Late Roman Silchester: Excavations in Insula IX Since 1997. Britannia Monograph Series no. 22: 189-195.

- 2012: A review of the Romano-British dog. In: Fulford, M.; Clarke, A. \& Eckardt, H. (eds.): Silchester and the Study of Romano-British Urbanism. Journal of Roman Archaeology, Supp. Series 90: 16511684.

- In press: Tiny dog from Iron-Age Silchester. In: Fulford, M.; Clarke, A.; Durham, E. \& Pankhurst, N. (eds.): Late Iron Age Calleva: the pre-conquest occupation at Silchester Insula IX, London, Society for the Promotion of Roman Studies, Britannia Monograph.

Corbett, L. 1995: The Dingo in Australia and Asia. University of New South Wales Press, Sydney.

Crockford, S.J. 2000: Dog evolution: a role for thyroid hormone physiology in domestication changes. In: Crockford, S.J. (ed.): Dogs Through Time: an Archaeological Perspective: 11-20. Proceedings of the $1^{\text {st }}$ 
I.C.A.Z. Symposium on the history of the domestic dog. B.A.R. (International Series) 889. Oxford.

DAVIS, S.J.M. 1997: Animal bones from the Roman site at Redlands Farm, Stanwick, Northamptonshire, 1990 excavation. Ancient Monuments Laboratory Reports Series 106/97.

De Grossi-Mazzorin, J. \& Tagliacozzo, A. 2000: Morphological and osteological changes in the dog from the Neolithic to the Roman period in Italy. In: Crockford, S.J. (ed.): Dogs Through Time: an Archaeological Perspective: 141-161. Proceedings of the $1^{\text {st }}$ I.C.A.Z. Symposium on the history of the domestic dog. B.A.R. (International Series) 889. Oxford.

Drake, A.G. 2004: Evolution and development of the skull morphology of canids: an investigation of morphological integration and heterochrony. Ph.D. dissertation, University Massachusetts, Amherst.

- 2011: Dispelling dog dogma: an investigation of heterochrony in dogs using 3D geometric morphometric analysis of skull shape. Evolution and Development 13: 204-213.

Drake, A.G. \& Klingenberg, C.P. 2008: The pace of morphological change: historical transformation of skull shape in St. Bernard dogs. Proceedings of the Royal Society B: Biological Sciences 275: 71-76.

FARELlo, P. 1995: I cani tardo-antichi rinvenuti in un condoto fognario de Classe (RA). Estratto da Padusa Quaderni 1: 295-308.

Fillios, M.A. \& Taçon, P.S.C. 2016: Who let the dogs in? A review of recent genetic evidence for the introduction of the dingo to Australia and implications for the movement of people. Journal of Archaeological Science: Reports http://dx.doi.org/10.1016/j.jasrep.2016.03.001, pp. 1-9.

Goodrich, E.S. 1958: Studies on the Structure \& Development of Vertebrates. Vol. I: 1-485. Dover Publications, New York.

Grant, A. 1984: Animal husbandry, in Danebury: An Iron Age Hillfort in Hampshire, Vol. 2: The Excavations 1969-1978. Council for British Archaeology (CAB) Research Reports 52: 533-563.

HaLl, S. 2000: Indigenous domestic dogs of southern Africa: an introduction. In: Blench, R.M. \& MacDonald, K.C. (eds.): The Origins and Development of African Livestock: Archaeology, Genetics, Linguistics and Ethnography: 302-311. University College of London Press, London.

Hammer, Ø.; Harper, D.A.T. \& Ryan, P.D. 2001: PAST: Paleontological statistics software package for education and data analysis. Palaeontologica Electronica 4: 1-9. Available at http://palaeo-electronica. org/2001_1/past/issue1_01.htm.
HARCOURT, R.A. 1974: The dog in prehistoric and early historic Britain. Journal of Archaeological Science 1: $151-175$.

Huber, W. 1974: Biometrische analyse der Brachycephalie beim Haushund. L'Année Biologique 13(3-4): 135-141.

Kohler-Matznick, J.; Brisbin, I.L.jr.; Feinstein, M. \& Bulmer, S. 2003: An updated description of the New Guinea singing dog (Canis hallstromi, Troughton 1957). Journal of Zoology (London) 261: 109-118.

KruSKA, D. 1988: Mammalian domestication and its effect on brain structure and behavior. In: Jerison, H.J. \& Jerison, I. (eds.): Intelligence and Evolutionary Biology, NATO ASI Series vol. G17: 211-250.

Larson, G.; Karlsson, E.K.; Perri, A.; Webster, M.T.; Ho, S.Y.W.; Peters, J.; Stahl, P.W.; PIPER, P.J.; LingaAs, F.; Fredholm, M.; Comstock, K.E.; Modiano, J.F.; Schelling, C.; Agoulnik, A.L.; Leegwater, P.A.; Dobney, K.; Vigne, J-D.; Vila, C.; Andersson, L. \& LindBLAD-ToH, K. 2012: Rethinking dog domestication by integrating genetics, archeology, and biogeography. Proceedings of the National Academy of Sciences, USA 109: 1-6.

Lawrence, B. \& Reed, C.A. 1983: The dogs of Jarmo. In: Braidwood, L.S.; Braidwood, R.J.; Howe, B.; Reed, C.A. \& Watson, P. (eds.): Prehistoric Archaeology along the Zagros Flanks: 485-494. University of Chicago Oriental Institute Publication 1.

LÜPS, P. 1974: Biometrische Untersuchungen an der Schadelbasis des Haushundes. Zoologischer Anzeiger 192: 383-413.

LutTSCHWAGER, J. 1965: Ein zwerghund aus römischen Graberfeld and der Berliner Strasse zu Heidelberg-Neuenheim. Zeitschrift für Saügeteirkunde 30: 24-30.

Mackinnon, M. \& Belanger, K. 2002: In sickness and health: care for an arthritic Maltese dog from the Roman cemetery of Yasmina, Carthage, Tunisia. In: Snyder, L.M. \& Moore, E.A. (eds.): Dogs and People in Social, Working, Economic or Symbolic Interaction: $38-43$. Proceedings of the $9^{\text {th }}$ ICAZ Conference, Durham. Oxbow Books 85. Oxford.

Maltby, M. 1987: Animal bones from the excavations at Owslebury, Hampshire: an Iron Age and early Romano-British settlement. English Heritage AML Report, 6/87. London.

Nussbaumer, M. 1978: Biometrischer vergleich der Topogenesemuster an der Schädelbasis kleiner und mittelgrosser Hunde. Sonderdruck aus Zeitschrift für Tierzüchtung und Züchtungsbiologie 95: 1-14.

- 1982: Über die Variabilität der dorso-basalen Schädelknickungen bei Haushunden [On the variabil- 
ity of dorso-basal curvatures in skulls of domestic dogs]. Zoologischer Anzeiger 209: 1-32.

OnaR, V.; Pazvant, G.; Gezer InCe, N.; Alpak, H.; JaneCZEK, M. \& KizILTAN, Z. 2013: Morphometric analysis of the foramen magnum of Byzantine dogs excavated in Istanbul Yenikapi at the side of Theodosius harbour. Mediterranean Archaeology and Archaeometry 13: $135-142$.

Parker, H.G. et al. 2009: An expressed Fgf4 retrogene is associated with breed-defining chondrodysplasia in domestic dogs. Science 325: 995-998.

Phillips, C.; Baxter, I.L. \& Nussbaumer, M. 2009: The application of discriminant function analysis to archaeological dog remains as an aid to the elucidation of possible affinities with modern breeds. Archaeofauna 18: 51-64.

RACKHAM, J. 1979: Rattus rattus: the introduction of the black rat into Britain. Antiquity 53: 112-120.

REED, C.A. 1961: Osteological evidences for prehistoric domestication in southwestern Asia. Zeitschrift für Tierzüchtung und Züchstungsbiologie 76(1): 31-38.

- 1969: The pattern of animal domestication in the prehistoric Near East. In: Ucko, P.J. \& Dimbleby, G.W. (eds.): The Domestication and Exploitation of Plants and Animals: 361-380. Aldine Press, Chicago.

- 1983: Archaeozoological studies in the Near East: a short history (1960-1980). In: Braidwood, L.S. et al. (eds.): Prehistoric Archaeology along the Zagros Flanks: 511-536. Oriental Institute Publications no. 105. University of Chicago.

RöHRs, V.M. 1985: Cephalization, neocorticalization and the effects of domestication on brains in mammals. In: Duncker, H.R. \& Fleischer, G. (eds.): Function- al Morphology in Vertebrates: 544-547. G. Fischer, Stuttgart.

Simoens, P.; Poels, P. \& Lauwers, H. 1994: Morphometric analysis of the foramen magnum in Pekingese dogs. American Journal of Veterinary Research 55: 34-39.

Smith, B.P. \& Litchfield, C.A. 2009: A review of the relationship between indigenous Australians, dingoes (Canis dingo) and domestic dogs (Canis familiaris). Anthrozöos 22(2): 111-128.

Thalmann, O. et al. 2013: Complete mitochondrial genomes of ancient canids suggest a European origin of domestic dogs. Science 342: 871-874.

Turnbull, P.F. \& Reed, C.A. 1974: The fauna from the terminal Pleistocene of Palegawra Cave, a Zarzian occupation site in Northeastern Iraq. Fieldiana: Anthroplogy 63(3): 1-36.

Watson, A.G.; De Lahunta, A. \& Evans, H.E. 1989: Dorsal notch of foramen magnum due to incomplete ossification of occipital bone in dogs. Journal of Small Animal Practice 30: 666-673.

YaLden, D. 1999: The History of British Mammals. T. \& A. D. Poyser, London.

ZEDER, M.A. 2006: A critical assessment of markers of initial domestication in goats (Capra hircus). In: Zeder, M.A.; Emschwiller, E.; Smith, B. \& Bradley, D. (eds.): Documenting Domestication: New Genetic and Archaeological Paradigms: 181-206. The University of California Press, Berkeley.

- 2012: The domestication of animals. Journal of Anthropological Research 68(2): 161-190.

- 2015: Core questions in domestication research. Proceedings of the National Academy of Sciences USA 112(11): 3191-3198. 